\title{
Characterising primary productivity measurements across a dynamic western boundary current region
}

\author{
Jason D. Everette,b,c,*, Martina A. Doblin ${ }^{\mathrm{b}, \mathrm{c}}$ \\ ${ }^{a}$ Evolution 83 Ecology Research Centre, School of Biological Earth and Environmental \\ Sciences, University of New South Wales, Sydney NSW 2052, Australia \\ ${ }^{b}$ Plant Functional Biology and Climate Change Cluster, Faculty of Science, University of \\ Technology Sydney, PO Box 123 Broadway, Sydney NSW 7, Australia \\ ${ }^{c}$ Sydney Institute of Marine Science, Mosman NSW 2088, Australia
}

\begin{abstract}
Determining the magnitude of primary production $(\mathrm{PP})$ in a changing ocean is a major research challenge. Thousands of estimates of marine PP exist globally, but there remain significant gaps in data availability, particularly in the Southern Hemisphere. In-situ PP estimates are generally single-point measurements and therefore we rely on satellite models of PP in order to scale up over time and space. To reduce the uncertainty around the model output, these models need to be assessed against in-situ measurements before use. This study examined the vertically-integrated productivity in four water-masses associated with the East Australian Current (EAC), the major western boundary current (WBC) of the South Pacific. We calculated vertically integrated PP from shipboard ${ }^{14} \mathrm{C}$ PP estimates and then compared them to estimates from four commonly used satellite models (ESQRT, VGPM, VGPM-Eppley, VGPM-Kameda) to assess their utility for this region. Vertical profiles of the water-column show each water-mass had distinct temperature-salinity signatures. The depth of the fluorescence-maximum $\left(f_{\max }\right)$ increased from onshore (river plume) to offshore (EAC) as light penetration increased. Depth integrated PP was highest in river plumes $\left(792 \pm 181 \mathrm{mg} \mathrm{C} \mathrm{m}^{-2} \mathrm{~d}^{-1}\right)$ followed by the EAC $\left(534 \pm 116 \mathrm{mg} \mathrm{C} \mathrm{m}^{-2}\right.$ $\left.\mathrm{d}^{-1}\right)$, continental shelf $\left(140 \pm 47 \mathrm{mg} \mathrm{C} \mathrm{m}^{-2} \mathrm{~d}^{-1}\right)$ and cyclonic eddy waters (121
\end{abstract}

\footnotetext{
* Corresponding Author

Email address: Jason.Everett@unsw.edu.au (Jason D. Everett)
}

Preprint submitted to Deep Sea Research Part I: Oceanographic Research PapersFebruary 16, 2015 
$\left.\pm 4 \mathrm{mg} \mathrm{C} \mathrm{m}{ }^{-2} \mathrm{~d}^{-1}\right)$. Surface carbon assimilation efficiency was greatest in the EAC (301 $\left.\pm 145 \mathrm{mg} \mathrm{C}(\mathrm{mg} \mathrm{Chl-a})^{-1} \mathrm{~d}^{-1}\right)$ compared to other water masses. All satellite primary production models tested underestimated EAC PP and overestimated continental shelf PP. The ESQRT model had the highest skill and lowest bias of the tested models, providing the best first-order estimates of PP on the continental shelf, including at a coastal time-series station, Port Hacking, which showed considerable inter-annual variability (155-2957 $\left.\mathrm{mg} \mathrm{C} \mathrm{m}^{-2} \mathrm{~d}^{-1}\right)$. This work provides the first estimates of depth integrated PP associated with the East Australian Current in temperate Australia. The ongoing intensification of all WBCs makes it critical to understand the variability in PP at the regional scale. More accurate predictions in the EAC region will require vertically-resolved insitu productivity and bio-optical measurements across multiple time scales to allow development of other models which simulate dynamic ocean conditions.

Keywords:

East Australian Current, ${ }^{14} \mathrm{C}$ carbon uptake, euphotic depth, depth-integrated PP models, primary production, boundary current, satellite observations

\section{Introduction}

Marine primary production (PP) is a fundamental measure of the ocean's capacity to convert carbon dioxide to particulate organic carbon at the base of the food-web and sets the upper limit for ocean productivity (Eppley and Peterson, 1979). Microscopic phytoplankton are primarily responsible for marine primary productivity, with $29 \%$ of total ocean PP estimated to occur within continental shelf seas (coastal waters), comprising only $11 \%$ of the ocean's surface area (Longhurst et al., 1995).

Direct measurements of PP are undertaken using a variety of methods including ${ }^{14} \mathrm{C}$ (Steemann-Nielsen, 1952), ${ }^{13} \mathrm{C}$ (Hama et al., 1983), chlorophyll $a$ (Chl-a) fluorescence (Lawrenz et al., 2013) and oxygen isotopes (Juranek and Quay, 2010). These measurements can be time-consuming and are inherently variable over short temporal and spatial scales (Chassot et al., 2010). They 
are also spatially and temporally limited and require multiple depth (or integrated) sampling (Kahru et al., 2009). Scaling these relatively sparse discrete measurements to regional, let alone basin-scale or global projections, remains a significant challenge, particularly if we are to understand the consequences of projected changes in coastal and basin-scale ocean circulation (Wu et al., 2012).

While thousands of measurements of marine primary productivity have been made throughout the world's oceans (e.g. ClimPP; see Friedrichs et al. (2009)), there remain significantly under-sampled regions, including much of the temperate Southern Hemisphere. In many cases it is unreasonable to wait for large, replicated in-situ datasets in order to investigate variability in regional PP. Scaling up over space and time therefore requires numerical models that quantitatively relate readily measured parameters to primary productivity. For some regions, this necessarily involves estimating primary production from satellitederived estimates of bio-optical properties such as Chl-a (Behrenfeld and Falkowski, 1997b; Behrenfeld et al., 2005).

Coastal regions affected by western boundary currents (WBC), are of particular physical and biological significance. WBCs move oligotrophic waters poleward, displacing cooler waters, generating mesoscale eddies (Everett et al., 2012) and inducing coastal-upwelling which increases near shore nutrient stocks (Roughan and Middleton, 2002; Suthers et al., 2011). WBCs therefore set up steep cross-shelf gradients in resources for phytoplankton growth and are highly dynamic, further enhancing the need for relatively frequent, synoptic assessments of PP.

In this study, we undertake a spatial survey of PP in temperate coastal waters affected by the East Australian Current (EAC) and use a range of modelling approaches to estimate PP in different water masses. First we use shipboard ${ }^{14} \mathrm{C}$ measurements collected in spring to estimate the vertically-integrated productivity of different water masses associated with this WBC. We then scale up measurements of PP using four different satellite models. PP estimates from models such as the vertically generalized production model (VGPM) described by Behrenfeld and Falkowski (1997a) have typically been validated in the North 
Atlantic and North Pacific waters (Saba et al., 2010; Friedrichs et al., 2009; Carr et al., 2006). PP model assessments have not yet been undertaken in the Western Tasman Sea, a hotspot for global warming (Wu et al., 2012). In order to apply these models to a range of scientific questions including fisheries management (Chassot et al., 2011), identifying fisheries hotspots (Zainuddin et al., 2006) and characterising ocean ecosystems (Chassot et al., 2010), we need to understand their limitations as a first step to their application in Southern Hemisphere waters.

The aims of this study are to: 1 ) examine how ${ }^{14} \mathrm{C}$ estimates of $\mathrm{PP}$ change with depth and water-mass in the western Tasman Sea; 2) compare verticallyintegrated shipboard ${ }^{14} \mathrm{C}$ PP estimates with modelled estimates derived from satellite-based measures and 3) use the satellite model with the highest skill to examine the temporal patterns of PP at PH100, a long-term coastal time-series station established south of Sydney in the 1940s. Despite the limited spatial and temporal coverage, this work represents the first assessment of PP model efficiency in these waters and provides critically important PP data from water masses associated with this dynamic WBC.

\section{Methods}

In-situ measurements and water sampling

The study domain was in the western Tasman Sea (Fig. 1) and extended from $29^{\circ} \mathrm{S}$ to $36^{\circ} \mathrm{S}$ and eastward to $155^{\circ} \mathrm{E}$, spanning subtropical and temperate latitudes. Sampling was timed to coincide with the spring bloom, when Chla biomass is at its highest (Everett et al., 2014). Hydrographic, optical and biogeochemical properties were sampled from 15-31 October 2010 on board the R/V Southern Surveyor.

Vertical profiles were completed (measuring depth, temperature, salinity (PSS-78) and fluorescence) using a Seabird SBE911 and Chelsea AquaTracker fluorometer mounted on a CTD rosette. Water samples were collected for Chl-a analysis using $10 \mathrm{~L}$ Niskin bottles. These samples were taken at the surface, 
and nominal depths of 10, 25, 50, 75 and $100 \mathrm{~m}$. The closest bottle-depth was adjusted to sample the fluorescence-maximum $\left(f_{\max }\right)$ based upon the fluorescence profile on the downcast. Water samples were also taken for ${ }^{14} \mathrm{C}$ uptake analysis at the surface and fluorescence-maximum (see details below).

Water-masses were differentiated by examining location, geostrophic velocities (Fig. 1) and temperature and salinity profiles (Fig. 2). These water-masses were defined as - river plumes ( 5 stations), continental shelf ( 4 stations), cyclonic eddy (2 stations) and East Australian Current (EAC; 4 stations; Table 1).

At each station the mixed layer depth (MLD; Table 1) was defined as the minimum depth at which either of the following criteria was satisfied:

$$
\begin{gathered}
T<T_{10 m}-0.4^{\circ} C \\
S>S_{10 m}+0.03
\end{gathered}
$$

where $\mathrm{T}$ and $\mathrm{S}$ are temperature and salinity at each depth and $T_{10 m}$ and $S_{10 m}$ is temperature and salinity at $10 \mathrm{~m}$ depth (Condie and Dunn, 2006).

\section{Bio-optical measurements}

Water-column irradiance measurements were taken using a free-falling hyperspectral photometer (Range: 350-800 nm, Resolution: $10 \mathrm{~nm}$; Optical Profiler, Satlantic USA; hereafter photometer) at 10 of the stations. The number of photometer deployments were limited due to ocean conditions and operational requirements. Depth profiles of photosynthetically active radiation (PAR) were calculated by integrating the irradiance between $400-700 \mathrm{~nm}$. At stations where the photometer wasn't deployed, PAR profiles were derived using a downwelling irradiance (PAR) sensor (QCP-2 Log Quantum Cosine Irradiance Sensor) which was mounted on the CTD rosette. The vessel was orientated to ensure the PAR sensor was deployed in the sun.

Depth specific light attenuation (Kirk, 2011) was calculated using: 


$$
k_{d}(z)=-\frac{1}{P A R_{z}} \frac{d P A R_{z}}{d z}
$$

where $P A R_{z}$ is depth-specific photosynthetically available radiation $(\mu \mathrm{mol}$ photons $\mathrm{m}^{-2} \mathrm{~s}^{-1}$ ) and $z$ is depth of measurement $(\mathrm{m})$. Water-column average irradiance-weighted $k_{d}$ was calculated as in (Kirk, 2011):

$$
k_{d}=\frac{\int_{0}^{\infty} k_{d}(z) P A R_{z} d z}{\int_{0}^{\infty} P A R_{z} d z}
$$

A paired t-test showed there was no significant difference in PAR $(\mathrm{t}=1.386$, $\mathrm{df}=13, \mathrm{p}=0.19)$ at the discrete ${ }^{14} \mathrm{C}$ measurement depths or $k_{d}(\mathrm{t}=0.1792$, $\mathrm{df}=9, \mathrm{p}=0.86)$ derived from either the PAR sensor $(\mathrm{CTD})$ or free-falling photometer.

The euphotic depth of the water-column (the depth at which irradiance reaches $1 \%$ of the surface irradiance), was calculated at each station using:

$$
z_{e u}=\frac{1}{k_{d}}
$$

and the optical depth of the water-column was calculated as:

$$
\zeta=k_{d} z
$$

In this equation the specified optical depth $(\zeta)$ corresponds to different physical depths $(z)$ but to the same overall diminution of irradiance, in waters of differing optical properties (Kirk (2011); Table 2).

\section{HPLC-derived chlorophyll a concentration}

Samples for in situ Chl-a analysis $\left(\mathrm{Chl}_{H, z}\right)$ were collected on $\mathrm{GF} / \mathrm{F}$ filters (Whatman) using gentle filtration $(<5 \mathrm{mmHg})$ and stored in cryo-vials in liquid nitrogen before being analysed back on shore. The pigments were extracted in $100 \%$ methanol in the dark at $4{ }^{\circ} \mathrm{C}$ and analysed by High Performance Liquid Chromatography (HPLC) using a Waters (Milford, MA, USA) Alliance HPLC, comprising a 2695XE separations module with column heater and refrigerated autosampler and a 2996 photo-diode array detector, following a modified version 
of the Van Heukelem and Thomas (2001) method (see Hassler et al. (2012) for details). Concentrations of $\mathrm{Ch}_{\mathrm{H}, \mathrm{z}}$ were determined from standards from SigmaAldrich (Sydney, NSW, Australia).

\section{Vertical fluorescence profiles}

In-situ Chl-a fluorescence intensity is reduced at high ambient light intensities, a process called non-photochemical quenching (NPQ; Falkowski and Kolber, 1995). To correct for the reduced estimate of Chl-a fluorescence during daylight hours, a light-dependent correction of the vertical fluorescence profiles was developed following Behrenfeld and Boss (2006):

$$
F l u_{c, z}=F l u_{q, z} \times\left(0.3+0.7 \times \exp ^{\left(-0.001 \times P A R_{z}\right.}\right)^{-1} ;
$$

where $F l u_{\mathrm{c}, \mathrm{z}}$ is the corrected estimate of fluorescence at each depth, Flu $u_{q}$ is the estimate of fluorescence without correction at each depth, and $P A R_{z}$ is the light ( $\mu \mathrm{mol}$ photons $\mathrm{m}^{-2} \mathrm{~s}^{-1}$ ) at depth $z(\mathrm{~m})$ of the observation. The possible fractional reduction in fluorescence yield due to NPQ is 0.3 to 1.0.

Following the correction of $\mathrm{NPQ}, \mathrm{Chl}_{\mathrm{H}, \mathrm{z}}$ from $\mathrm{CTD}$ casts was used to calibrate the vertical fluorescence profile $\left(\mathrm{df}=131\right.$, $\mathrm{t}$-stat $\left.=25.966, \mathrm{p}<0.01, \mathrm{r}^{2}=0.78\right)$ using the exponential equation:

$$
C h l_{F, z}=3.768 \times 10^{-10} \times F l u_{c, z}^{5.9348}
$$

In the following sections, the best available Chl-a product was used for each analysis. $\mathrm{Chl}_{\mathrm{H}, \mathrm{z}}$ was used for the calculation of depth-specific (surface and $f_{\max }$ ) primary production parameters (below). For the integrated PP, the vertical $\mathrm{Chl}_{\mathrm{F}, \mathrm{z}}$ profile from the fluorometer was used. Integrated Chl-a $\left(\mathrm{Chl}_{\mathrm{F}, \mathrm{int}}\right.$ : $\mathrm{mg}$ $\mathrm{m}^{-2}$ ) was calculated to the $1 \%$ euphotic depth using a trapezoidal integration of $\mathrm{Chl}_{\mathrm{F}, \mathrm{z}}$.

Depth-specific primary production calculations using ${ }^{14} C$

${ }^{14} \mathrm{C}$ uptake measurements were made at 22 stations, across 4 water-masses (river plume, continental shelf, cyclonic eddy and EAC) and PhotosynthesisIrradiance (P-I) curves for carbon fixation were determined for the surface and 
$f_{\max }$. To maximise the spatial coverage, we reduced the vertical resolution of sampling for PP and considered the surface sample representative of the upper mixed layer and the $f_{\max }$ sample representative of the lower euphotic zone. P-I curves were obtained according to the small bottle technique (Lewis and Smith, 1983). Water samples were transferred from the Niskin bottles into acid-washed dark bottles and stored in a cooler (15-30 minutes) until ${ }^{14} \mathrm{C}$ incubations. From each sample, $162 \mathrm{ml}$ of water was transferred to a $500 \mathrm{ml}$ black-coated bottle with addition of $171 \mu \mathrm{Ci}$ of $\mathrm{NaH}_{14} \mathrm{CO}_{3}$. Seven $\mathrm{ml}$ of this solution was then transferred into $20 \mathrm{ml}$ scintillation vials. Vials were incubated for 1 hour under seven different light intensities made with blue and neutral films that simulated underwater light fields; Lee Filters, Burbank, CA, USA). The first was a dark chamber $\left(0 \mu \mathrm{mol}\right.$ photons $\left.\mathrm{m}^{-2} \mathrm{~s}^{-1}\right)$, and the remaining six intensities ranged from 20 to $2000 \mu \mathrm{mol}$ photons $\mathrm{m}^{-2} \mathrm{~s}^{-1}$. Three replicates were carried out for each of the light intensities with light measured daily in each with a $4 \pi$ sensor (Biospherical Instruments). Incubations took place under controlled insitu temperatures. Samples were fixed with $250 \mu \mathrm{L}$ of $6 \mathrm{M} \mathrm{HCl}$ to stop ${ }^{14} \mathrm{C}$ uptake and were agitated for a minimum of 3 hours to remove unfixed ${ }^{14} \mathrm{C}$. Finally 10 $\mathrm{ml}$ of Aquassure (Perkin Elmer) scintillation cocktail was added to each sample and the activity (disintegrations per minute; DPM) was measured on a Packard TriCarb 2 TR scintillation counter. Time-zero counts were taken to determine background ${ }^{14} \mathrm{C}$ and $100 \%$ counts were used to determine the specific activity of the working solution.

Following ${ }^{14} \mathrm{C}$ analysis, the time zero control was subtracted from each sample and DPM values were converted to carbon-fixed, before the sample was normalised by $\mathrm{Chl}_{\mathrm{H}, \mathrm{z}}$ values. A least squares non-linear regression using the model of Platt et al. (1980) was fitted to the data. The chlorophyll-specific carbon fixation rate $\left(P_{z}^{b}\right.$; assimilation efficiency) at a given light intensity was calculated at the surface and $\mathrm{f}_{\max }$ by:

$$
P_{z}^{b}=P_{\max }^{b}\left[\left(1-e^{-\alpha^{b} P A R_{z} / P_{\max }^{b}}\right)\left(e^{-\beta^{b} P A R_{z} / P_{\max }^{b}}\right)\right]
$$


where $P_{\max }^{b}$ is the light-saturated photosynthetic rate, $P A R_{z}$ is PAR at each depth $\left(\mu \mathrm{mol} \mathrm{m} \mathrm{m}^{-2} \mathrm{~s}^{-1}\right), \alpha^{b}$ is the chlorophyll-specific initial slope of the lightlimited section of the P-I curve $\left(\mathrm{mg} \mathrm{C}(\mathrm{mg} \mathrm{Chl-a})^{-1} \mathrm{~h}^{-1}\left(\mu \mathrm{mol} \mathrm{m}{ }^{-2} \mathrm{~s}^{-1}\right)^{-1}\right)$ and $\beta^{b}$ is the chlorophyll-specific photo-inhibition parameter (mg C (mg Chla) $)^{-1} \mathrm{~h}^{-1}\left(\mu \mathrm{mol} \mathrm{m}{ }^{-2} \mathrm{~s}^{-1}\right)^{-1}$; Table 3$)$. Data from 15 stations are presented here (Fig. 1) because 7 stations were unable to be used due to incomplete data, failed equipment or non-convergence of ${ }^{14} \mathrm{C}$ measurements with the P-I model (Platt et al., 1980).

The following equation was used to obtain depth-specific (surface and fmax) ${ }^{14} \mathrm{C}$ primary productivity estimates $\left(\mathrm{PP}_{z} ; \mathrm{mg} \mathrm{C} \mathrm{m}{ }^{-3} \mathrm{~h}^{-1}\right)$ :

$$
P P_{z}=P_{z}^{b} \times C h l_{F, z}
$$

\section{Vertically-integrated daily primary production measurements}

Vertically-integrated daily primary production was then calculated by applying the photosynthetic parameters $\left(\alpha^{b}, \beta^{b}\right.$ and $\left.P_{\max }^{b}\right)$ from the surface and $f_{\max }$ in a 2-box model approach through the water column. Hourly $P_{z}^{b}$ at 1 m intervals (Equation 9) were calculated using hourly PAR profiles, vertical $C h l_{\mathrm{F}, \mathrm{z}}$ profiles and the P-I model of Platt et al. (1980).

Hourly incoming solar radiation was estimated from orbital cycles (Brock, 1981) and PAR just below the surface $\left(\mathrm{PAR}_{0}\right)$ was determined by subtracting surface albedo. Surface albedo, as a function of zenith angle is calculated using Fresnels equation (Kirk, 2011). A $20 \%$ reduction was applied to the incoming PAR to account for the mean observed difference between orbital cycles and the downward solar radiation flux for the region during the study period (as determined from daily satellite (MODIS) PAR estimates, using methods described in Baird et al. (2007)). Hourly PAR profiles $\left(\mathrm{PAR}_{z, t}\right)$ through the water column were then able to be calculated at each CTD location using the station-specific $k_{d}$ (estimated using Equation 4).

$$
P A R_{z, t}=P A R_{0, t} \exp ^{-k_{d} z}
$$


The water-column was split into regions above and below the MLD to coincide with the locations of the ${ }^{14} \mathrm{C}$ incubations. At all stations, the $f_{\max }$ occurred below the MLD (Table 1) and therefore the surface-derived coefficients $\left(\alpha^{b}, \beta^{b}\right.$ and $\left.P_{\max }^{b}\right)$ were applied from the surface to the MLD and the second set of coefficients (measured at the $f_{\max }$ ) from the MLD to the bottom of the euphotic zone (1\% surface irradiance). To prevent the sudden change of parameter values above and below the MLD, a $20 \mathrm{~m}$ moving average was applied throughout the water-column, smoothing the transition from the surface coefficients. This approach of applying the coefficients through the upper MLD is not unreasonable as photosynthetic parameters are relatively consistent within the upper MLD (Westwood et al., 2011).

Hourly $P_{z, t}^{b}$ was then recalculated (Equation 9) at $1 \mathrm{~m}$ intervals through the water-column using the hourly- and depth-resolved light intensity $\left(I_{z, t}\right)$, productivity coefficients $\left(\alpha^{b}, \beta^{b}\right.$ and $\left.P_{\max }^{b}\right)$ and $C h l_{F l u, z}$. This was integrated over the whole day using a trapezoidal integration to calculate vertically integrated daily primary production.

$$
P P=\int_{1}^{24} \int_{s u r f}^{z_{e u}} P_{z, t}^{b} \times C h l_{F, z}
$$

\section{Satellite derived primary production estimates}

There are numerous satellite-based models of primary productivity which can be separated into broad categories due to their formulation including depthintegrated/wavelength-integrated (the most common), depth-resolved/wavelengthintegrated or depth-resolved/wavelength-resolved (Friedrichs et al., 2009). This is the first attempt to assess PP models in this EAC region, so there was no clear choice of PP model. We therefore chose to evaluate four depth- and wavelength-integrated models which are commonly used in primary production studies (Friedrichs et al., 2009; Saba et al., 2011; Carr et al., 2006). Due to the significant concentrations of coloured dissolved organic matter (CDOM) and suspended particulates within the river plumes, these stations were not included in the model assessments, as both are known to significantly influence 
the ability of satellites to estimate Chl-a (Darecki and Stramski, 2004; Siegel et al., 2005).

The simplest model formulation was the Eppley-Square-Root Model (ESQRT) (Eppley et al., 1985) and the three other models were variants of the Vertically Generalized Production Model (VGPM) (Behrenfeld and Falkowski, 1997b). Chl-a based models were chosen because there is a considerable archive of pigment data from the region (Thompson et al., 2011), but other bio-optical data is very limited. The ESQRT model (Eppley et al., 1985) ignores all external forcings and assumes that the standing stock of phytoplankton (Chl-a) determines the photosynthetic rate. The VGPM (Behrenfeld and Falkowski, 1997b), is one of the most widely known and used depth-integrated/wavelengthintegrated models. Variants of the original VGPM have been developed and maintain a similar form but generally alter the parameterisation of $P_{o p t}^{b}$ (maximum Chl-a normalised productivity). VGPM uses a 7th order polynomial of Sea-Surface Temperature (SST) to calculate the maximum photosynthetic rate. The VGPM-Eppley model (Eppley, 1972) constrains $P_{o p t}^{b}$ as an exponential function of SST. The fourth and final model we tested was the VGPM-Kameda model (Kameda and Ishizaka, 2005) which uses both SST and surface Chl-a to constrain $P_{o p t}^{b}$ and is based on two assumptions: 1) that changes in Chl-a concentration result from changes in large-sized phytoplankton abundance, and 2) Chl-a specific productivity of phytoplankton tends to be inversely proportional to phytoplankton size.

The satellite inputs for these models were derived from the MODIS-Aqua satellite to match the timing of shipboard ${ }^{14} \mathrm{C}$ PP estimates. Satellite data was processed and provided by the Integrated Marine Observing System (IMOS; http://www.imos.org.au) at $1 \mathrm{~km}$ resolution. Due to the limited match-up data between the MODIS-Aqua satellite and shipboard measurements, the timelimits were relaxed to within 24 hours of in-situ sampling (Son et al., 2011; Le et al., 2013). A mean value from an area of $9 \times 9 \mathrm{~km}$ ( 81 pixels) was used.

Satellite data used in these models are: Sea Surface Temperature $\left(\mathrm{SST} ;{ }^{\circ} \mathrm{C}\right)$, OC3 Chlorophyll $a\left(\mathrm{Chl}_{\mathrm{S}} ; \mathrm{mg} \mathrm{m}^{-3}\right)$, and Photosynthetically Available Radia- 
tion (PAR; $\mu$ mol photons $\mathrm{m}^{-2} \mathrm{~d}^{-1}$ ). In order to assess the contribution of satellite-derived model inputs to overall model uncertainty (Saba et al., 2010), we reran each model using in-situ measurements of SST, $\mathrm{Chl}_{\mathrm{H}, \mathrm{z}}$ and $k_{d}$. Satellite estimates of PAR were still used as we didn't have daily measurements of PAR for each site. The models chosen are inherently insensitive to PAR inputs (Friedrichs et al., 2009) and thus variation due to satellite versus in-situ PAR measurements were not likely to alter the outcome of PP estimates.

\section{Assessment of satellite PP models}

To assess model performance we used the root mean square difference (RMSD) and model bias (B). The RMSD statistic assesses model skill such that models with lower values have higher skill, and the model bias assesses whether a model over- or under-estimates PP (Saba et al., 2010). For each model (satellite and CTD) we calculated the RMSD for $n$ samples of PP:

$$
R M S D=\left(\frac{1}{n} \sum_{i=1}^{n} \Delta(i)^{2}\right)^{1 / 2}
$$

where model-data misfit in $\log _{10}$ space $\Delta(i)$ is defined as:

$$
\Delta(i)=\log \left(P P_{m}(i)\right)-\log \left(P P_{d}(i)\right)
$$

where $P P_{m}(i)$ was modelled $\mathrm{PP}$ and $P P_{d}(i)$ represents shipboard ${ }^{14} \mathrm{C} \mathrm{PP}$ estimates at each site. To assess whether a model over- or underestimated PP we calculated each model's bias as:

$$
B=\overline{\log \left(P P_{m}\right)}-\overline{\log \left(P P_{d}\right)}
$$

\section{Port Hacking National Reference Station (PH100)}

To make a first order assessment of PP through time within the region, the best performing satellite model was used to assess the temporal patterns of $\mathrm{PP}$ at a historic time-series station on the continental shelf off Port Hacking (PH100; Fig. 1). The PH100 station has a 60 year time-series of physical and chemical properties. Since September 2009 it has been regularly sampled for 
additional biological properties. We used satellite data from January 2010-June 2014, for which there was corresponding in-situ $(25 \mathrm{~m})$ estimates of $\mathrm{Ch}_{\mathrm{H}, \mathrm{z}}$ ( $\mathrm{n}$ $=30)$. Modelled PP was calculated from both $\mathrm{Chl}_{\mathrm{S}}$ and $\mathrm{Chl}_{\mathrm{H}}$ and further information about the collection protocols are available from the IMOS portal (http://imos.aodn.org.au/imos/).

\section{Data analysis}

All data-analysis in this study was undertaken using MATLAB R2014B (Mathworks; Massachusetts, U.S.A.). Differences in physical, optical and biological properties of each water-mass were tested using a one-way Analysis of Variance (ANOVA). A pairwise-comparison, using Tukey's least significant difference procedure was used to determine where the differences were.

\section{Results}

River plume stations generally exhibited fresher surface waters (34.18-35.58) than other stations (Fig. 2) and were clustered in the northern part of the study domain $\left(28.9-29.4^{\circ} \mathrm{S}\right)$ where river outputs are larger. During the study period, the EAC was flowing along the edge of the continental shelf with a maximum geostrophic velocity of $1.6 \mathrm{~m} \mathrm{~s}^{-1}$ (Fig. 1A). EAC stations were offshore in the core of the EAC (Fig. 1) and had a temperature range of $21.4-22.5^{\circ} \mathrm{C}$ and a salinity of 35.45-35.52 in the upper $200 \mathrm{~m}$ of the water-column (Fig. 2B). The continental shelf stations were located in the southern part of the study domain off Seal Rocks (32.3-34.1 $\left.{ }^{\circ} \mathrm{S}\right)$. Offshore from the continental shelf stations, a cyclonic (cold-core) eddy was present $\left(32.3^{\circ} \mathrm{S}\right.$; Fig. 1). This eddy had formed in the Tasman Sea during winter and migrated westward towards the coast. Due to the presence of the eddy, the EAC retroflected away from the coast at this location, before wrapping around an anti-cyclonic eddy to the south $\left(34^{\circ} \mathrm{S}\right.$, $154.5^{\circ} \mathrm{E}$; Fig. 1). 


\section{Vertical water-column properties}

Vertical light attenuation $\left(k_{d}\right)$ within the river plumes $\left(0.37 \pm 0.26 \mathrm{~m}^{-1}\right)$ was significantly higher $\left(\mathrm{F}_{3,11}=3.89, \mathrm{p}=0.04\right)$ than in the $\mathrm{EAC}\left(0.06 \pm 0.001 \mathrm{~m}^{-1}\right)$, continental shelf $\left(0.09 \pm 0.014 \mathrm{~m}^{-1}\right)$ and cyclonic eddy $\left(0.07 \pm 0.002 \mathrm{~m}^{-1}\right)$. As a result, the euphotic depth $\left(z_{e u}\right)$ of the river plumes $(19 \pm 12 \mathrm{~m})$ was significantly shallower $\left(\mathrm{F}_{3,11}=30.21, \mathrm{p}<0.001\right)$ than all other water-masses (Table 1$)$, and the EAC euphotic depth $(75 \pm 2 \mathrm{~m})$ was significantly deeper than the continental shelf $(54 \pm 10 \mathrm{~m})$. There was little variability in the daily incoming irradiance (PAR), which ranged from 54.2-56.9 mol photons $\mathrm{m}^{-2} \mathrm{~d}^{-1}$ for all the stations during the spring sampling period.

Mixed layer depths were similar amongst stations $\left(\mathrm{F}_{3,11}=3.43, \mathrm{p}=0.056\right)$, however the vertical distribution of Chl-a differed. Not surprisingly, vertical profiles of the water-column show the depth of the Chl-a fluorescence maximum $\left(f_{\max }\right)$ increasing from onshore (continental shelf) to offshore (EAC) stations (Fig. 3A). River plumes had significantly shallower $f_{\max }\left(9 \pm 6 \mathrm{~m} ; \mathrm{F}_{3,11}=32.88\right.$, $\mathrm{p}<0.001)$ than all other water-masses, and the EAC $f_{\max }(59 \pm 9 \mathrm{~m})$ was significantly deeper than on the continental shelf $(37 \pm 9 \mathrm{~m})$. The $f_{\max }$ in the cyclonic eddy $(49 \pm 3 \mathrm{~m}$ ) was not significantly different to either the EAC or continental shelf. The $f_{\max }$ was within the euphotic depth for all stations, except for one river plume station (13; Table 1), and was generally at or below the MLD. The $f_{\max }$ was below the first optical depth at all stations (Table 1), suggesting the bulk of the phytoplankton biomass was below the depth of satellite penetration.

\section{Daily surface and integrated primary productivity}

Surface productivity $\left(\mathrm{PP}_{0}\right)$ was highest in the river plumes $(118.02 \pm 79 \mathrm{mg}$ $\left.\mathrm{C} \mathrm{m}^{-2} \mathrm{~d}^{-1}\right)$ compared to all other water-masses $\left(\mathrm{F}_{3,11}=6.52, \mathrm{p}<0.01\right)$. Integrated primary productivity $(\mathrm{PP})$ was significantly higher in the river plumes $\left(792.65 \pm 182 \mathrm{mg} \mathrm{C} \mathrm{m}^{-2} \mathrm{~d}^{-1}\right)$ compared to the EAC $\left(\mathrm{F}_{3,11}=24.89, \mathrm{p}<0.001\right)$ as a result of the maximum standing stock of Chl-a in the river plumes (Table 4). The PP of the $\operatorname{EAC}\left(533.57 \pm 116 \mathrm{mg} \mathrm{C} \mathrm{m}^{-2} \mathrm{~d}^{-1}\right)$ was significantly higher than the continental shelf and cyclonic eddy $\left(140.04 \pm 47 \mathrm{mg} \mathrm{C} \mathrm{m}^{-2}\right.$ 
$\mathrm{d}^{-1}$ and $121.37 \pm 4 \mathrm{mg} \mathrm{C} \mathrm{m}^{-2} \mathrm{~d}^{-1}$ respectively) as a result of the large euphotic depth. Furthermore, the efficiency of surface carbon assimilation $\left(P_{0}^{b}\right)$ was greatest in the EAC $\left.(300.61 \pm 145 \mathrm{mg} \mathrm{C} \mathrm{(mg} \mathrm{Chl-a})^{-1} \mathrm{~d}^{-1}\right)$ compared to all other water-masses $\left(\mathrm{F}_{3,11}=5.48, \mathrm{p}<0.02\right)$. Integrated carbon assimilation $\left(P^{b}\right)$ was significantly higher in the EAC $\left(123.17 \pm 25 \mathrm{mg} \mathrm{C}(\mathrm{mg} \mathrm{Chl}-\mathrm{a})^{-1} \mathrm{~d}^{-1}\right)$ compared to all other water-masses. The $P^{b}$ of the river plumes was significantly higher $\left(\mathrm{F}_{3,11}=18.3, \mathrm{p}<0.001\right)$ than the cyclonic eddy $(27.41 \pm 2 \mathrm{mg} \mathrm{C}$ $\left.(\mathrm{mg} \mathrm{Chl}-\mathrm{a})^{-1} \mathrm{~d}^{-1}\right)$ and continental shelf $\left(30.73 \pm 14 \mathrm{mg} \mathrm{C}(\mathrm{mg} \mathrm{Chl-a})^{-1} \mathrm{~d}^{-1}\right.$; Table 4).

The vertical distribution of $\mathrm{PP}_{z}$ peaked between 1 and 2 optical depths within the river plumes and between 2 and 4 optical depths in all other watermasses (Fig. 3E). This was well below the first optical depth which approximates the depth of satellite penetration. In contrast, $P_{z}^{b}$ peaked within two optical depths in all water-masses (Fig. 3C).

\section{Satellite model assessment of SE Australian waters}

Satellite models showed moderate correspondence with the shipboard ${ }^{14} \mathrm{C}$ PP estimates, but this was dependent on water mass (Fig. 4). Root mean square difference (RMSD) ranged from 0.29 to 0.48 and model bias ranged from 0.12 to 0.33 . The ESQRT model had the lowest RMSD (highest skill) and lowest bias (Table 5), which resulted in the best match with semi-empirical shipboard PP estimates when satellite-derived input data were used. A positive model bias showed the satellite models overestimated PP overall. In particular, PP was over-estimated in the shelf waters, and under-estimated in the EAC (Fig. 4).

When in-situ input data was used in the models, instead of satellite-derived values, model skill improved marginally for the VGPM suite of models (0.250.38 ) but marginally decreased for ESQRT (0.30; Table 5). Improvements were evident only in continental shelf and cyclonic eddy waters (Fig. 4 E-H) where waters are optically complex, but resulted in greater under-estimates of PP in the EAC. Regardless of input data sources, all models deviated from 1:1 (Fig. 4 A-D). 
Annual and seasonal trends in primary production

The ESQRT model was applied to the continental shelf off Port Hacking (PH100 station) to make a first order assessment of PP through time in this EAC-influenced region. The model assessment showed ESQRT has the highest skill and lowest bias when using satellite-derived data. From January 2010 to July 2013, Chl-a and PP show a seasonal cycle (Fig. 5A,B) with a peak in Chl-a biomass and PP occurring in spring (September/October) and a minimum occurring in late summer (February/March). Satellite-derived Chl follows a similar temporal pattern to in-situ Chl. Average daily satellite-derived PP at PH100 during 2010-2013 was $612 \mathrm{mg} \mathrm{C} \mathrm{m}{ }^{-2} \mathrm{~d}^{-1}$ (Fig. 5B). There was considerable inter-annual variability in PP, with values ranging from 155 to $2957 \mathrm{mg}$ $\mathrm{C} \mathrm{m}{ }^{-2} \mathrm{~d}^{-1}$.

\section{Discussion}

Understanding the PP of waters affected by WBCs is critical. WBCs are warming faster than other regions of the global ocean (Wu et al., 2012) and there is little understanding of how these changes will affect pelagic ecosystems. In particular we have low confidence in predictions of future fisheries yields because of uncertainty over future PP and its transfer to higher trophic levels (Brander, 2007). It is therefore important to quantify and understand the sources of variation in marine $\mathrm{PP}$ within the $\mathrm{EAC}$ region, where in-situ datasets are extremely limited compared to those published for other boundary current systems such as the Agulhas Current (Probyn et al., 1994) and the Gulf Stream (Mouw and Yoder, 2005).

Primary production in Australian waters and boundary currents

In global terms, temperate Australian coastal waters generally have low primary productivity (Chavez et al., 2011) due to the continent's low percentage of rainfall as runoff (average of 12\% compared to 33\% for North America; Arthington and Pusey (2003)), low relief and nutrient-poor soils (Davis and Koop, 2006). 
However, in our study region, wind- and EAC-induced upwelling intermittently brings nutrient-rich waters onto the shelf (Roughan and Middleton, 2002) resulting in elevated surface Chl-a (Everett et al., 2014), so it was therefore expected that the integrated PP of continental shelf and cyclonic eddy stations would be greater relative to the EAC. In contrast, our results show that the EAC had significantly higher integrated PP compared to both the continental shelf and cyclonic eddy stations. This may be a result of the limited vertical resolution of our ${ }^{14} \mathrm{C}$ measurements (and the associated uncertainty in vertical integration) but may also likely be the result of the greater depth range over which production occurred. An additional source of uncertainty in the EAC PP data are the relatively high estimates of $\mathrm{P}_{\max }^{b}$ in the surface waters. These high values are a result of the dependence of the PvsE parameters on the Chl-a biomass, which was low in the EAC $\left(0.03 \mathrm{mg} \mathrm{m}^{-3}\right)$. Low Chl-a in the EAC will affect the detectability of pigments by both HPLC and satellites, which may lead to more uncertainty in this match up than in other water masses. Despite this, the EAC PP recorded here is consistent with previous estimates (Furnas and Mitchell, 1987, 1996). With respect to PP in other regions around Australia, EAC waters appear to be more productive than the Leeuwin Current but support considerably lower PP than the north-west shelf, and parts of the Great Australian Bight and Southern Ocean (Table 6).

Areal estimates of PP in the EAC from this study are lower than those made for the core of the Gulf Stream (730-900 $\mathrm{mg} \mathrm{C} \mathrm{m}{ }^{-2} \mathrm{~d}^{-1}$; Mouw and Yoder (2005)), similar to the Kuroshio Current (70-620 mg C m${ }^{-2} \mathrm{~d}^{-1}$; Hung (1975)), but are higher than the Agulhas Current (85-109 mg C m${ }^{-2} \mathrm{~d}^{-1}$; Probyn et al. (1995); Mitchell-Innes (1967)). Western boundary currents are generally less productive than eastern boundary currents which are dominated by wind-driven coastal upwelling (Carr and Kearns, 2003). The average annual PP of eastern boundary currents (using the Howard-Yoder Mixed Layer Depth model) was estimated to range between 990 and $2490 \mathrm{mg} \mathrm{C} \mathrm{m}^{-2} \mathrm{~d}^{-1}$ (California Current and Benguela Current respectively; Carr and Kearns (2003)). The PP for the Benguela Current is almost five-times higher than what we estimate from the 
EAC using the shipboard ${ }^{14} \mathrm{C}$ PP estimates (Table 4) and six-times greater than the highest satellite estimate (Fig. 4).

\section{Satellite model performance in the Tasman Sea}

In regions with low data density such as the Tasman Sea, spatial or temporal dynamics of PP can only realistically be examined by supplementing in-situ data with model estimates. While our dataset is very small relative to others used to develop global satellite algorithms (Werdell and Bailey, 2005), it nevertheless has utility in guiding the future development of models to understand regional productivity in this dynamic western boundary current region. In this study, we use shipboard ${ }^{14} \mathrm{C}$ PP estimates to provide the first assessment of satellitederived PP models in the western Tasman Sea.

The satellite model skill in our study region ranges from 0.27-0.42 with a mean RMSD across all models of 0.34 (Table 5). Previous PP model assessments have used the same evaluation metrics (Saba et al., 2010; Kahru et al., 2009; Carr et al., 2006; Friedrichs et al., 2009). Saba et al. (2011) recently did a global assessment showing that the mean RMSD of all PP models varied from 0.16 in the Antarctic Polar Frontal Zone (high skill) to 0.44 in the Black Sea (low skill). While Saba's analysis did not include EAC-influenced waters, it is evident the satellite models tested in this study had low to moderate skill, underestimating vertically-integrated $\mathrm{PP}$ in the EAC and over-estimating $\mathrm{PP}$ on the shelf. Our data suggest that PP uncertainty arises from two major sources: complex optical properties on the shelf that influence satellite signals, and the accumulation of phytoplankton at depth in offshore EAC waters.

To examine the influence of optical complexity on in-situ model mismatch, we substituted satellite estimates of Chl-a (and temperature) with in-situ estimates and found that this improved PP estimates in continental shelf and cold core eddy waters, but not in the EAC. Model skill has often been improved when in-situ Chl-a data is used instead of satellite-derived inputs (Saba et al., 2010; Jacox et al., 2015). This is because in coastal (or upwelled) waters, the blue region of the water-leaving radiance signal used in many standard Chl-a satellite 
algorithms is affected by other optically-active constituents (coloured dissolved organic matter and detrital material) in addition to phytoplankton (Siegel et al., 2005). This can result in an over-estimate of Chl-a and therefore PP. Given the complex inherent optical properties of coastal waters (Cherukuru et al., 2014), it is clear that alternate bio-optical approaches are necessary to estimate PP (Huot et al., 2007). A viable avenue may be to develop light-absorption based approaches such as those used for the North Sea-Western English Channel region (Barnes et al., 2014).

The underestimation of the EAC PP by all models (Fig. 4) was likely influenced by the depth of the $\mathrm{f}_{\max }$ which was significantly deeper than the optical depth of satellites (Fig. 3B). Saba et al. (2010) showed that $90 \%$ of models underestimate PP at Station Aloha in the North Pacific subtropical gyre. This under-estimation was partially attributed to the deepening of the MLD, which was not captured by the satellite fields. The location of the PP within the water-column is therefore an important consideration (Jacox et al., 2015), as the satellite models evaluated in this study rely on assumptions about the vertical distribution of $\mathrm{PP}$, and much of the uncertainty in model-derived $\mathrm{PP}$ is attributed to uncertainty in the vertical distribution of PP (Buitenhuis et al., 2013).

\section{Overcoming data limitations and model complexity}

Scaling up limited PP data in this changing western boundary current region is a major research challenge. Narrowing uncertainty in PP estimates across the vertical and horizontal dimensions, as well as through time will require a mix of approaches. In this study we traded off vertical resolution in our carbon fixation measurements in order to improve the spatial coverage across water masses, resulting in obvious limitations. We also observed deep Chl-a maxima in offshore waters that were consistently under-estimated by satellite models. Thus, in the vertical dimension, a priority will be to make multiple depth measurements of PP to not only increase the accuracy of areal estimates, but also to understand vertical and horizontal nutrient enrichment processes and 
dynamics. Identifying the physical conditions that are associated with DCMs, and the specific set of environmental predictors that could describe the size of the DCM are also important research priorities.

In the horizontal dimension, this study showed that river plumes have high productivity relative to surrounding shelf water, however their spatial extent and temporal variability are relatively unknown. Understanding the implications of steep gradients in bio-optical properties across a relatively narrow continental shelf ( $\sim 15 \mathrm{~km}$ at its narrowest; $\left.31^{\circ} \mathrm{S}\right)$ suggests that standard satellite products with 1-4 km pixel size will have limited resolution to detect changes across the shelf and suggests that coupled physical-biogeochemical models should aim for kilometre-scale resolution. Fortunately, Chl-a variation in the along-shelf direction is considerably lower, with long-range spatial correlations in surface Chl-a extending from the study domain to Tasmania (Jones et al., 2015).

In addition to the limited horizontal and vertical information about PP in Tasman Sea waters, we have little understanding of its temporal variability. Studies have demonstrated short-term (Armbrecht et al., 2014) and seasonal (Everett et al., 2014) changes in coastal phytoplankton biomass using in-situ and satellite data respectively. However, there has never been a temporal assessment of $\mathrm{PP}$ in this region. Our analysis at the Port Hacking coastal time-series station indicates significant inter-annual variation in PP, suggesting that observation and modelling approaches need to capture dynamics at multiple temporal scales.

Given that the more complex satellite models evaluated here perform no better than the simplest ESQRT model, it would appear unwise to apply them in this region until we have a better understanding of the vertical and horizontal distribution of primary production, and can build relationships with readily measured environmental parameters. As in other regions, autonomous underwater gliders have the capacity to collect spatio-temporal data and help build and validate PP models (Jacox et al., 2015). Indeed gliders have been regularly deployed on the shelf in this EAC-influenced region to understand changes in physical properties (Everett et al., in press; Baird et al., 2011; Baird and Ridgway, 2012). 


\section{Concluding remarks}

Our PP estimates for the EAC are higher than similar studies in the Agulhas Current, but are of a similar magnitude to previous work in the Kuroshio Current and Coral Sea (EAC source waters). Satellite models underestimate the EAC PP, likely due to the depth of the phytoplankton in the water-column, and overestimate the PP of optically complex shelf waters. River plumes were shown to have high PP relative to the surrounding shelf waters, however their spatial and temporal extent are not well characterised in this region. In order to better understand PP within the EAC-influenced waters of the western Tasman Sea, significantly more measurements are required across multiple years and seasons. Initially these measurements can be used to quantify the productivity of different water-masses, but eventually will be needed to further validate the available biogeochemical (or other) models in order to scale up relatively sparse measurements through time and space. Depth-resolved or absorption-based models which take into account changing physiology and bio-optical properties of phytoplankton cells, may be more appropriate for use in regions such as the EAC, where the vertical location of the productivity is important, or coastal regions where the waters are more optically complex. The work presented here is the first step in this process, updating PP data for the western Tasman Sea from previous measurements made 25 years ago, and providing the first ever assessment of satellite-derived PP estimates in this EAC-influenced region.

\section{Acknowledgements}

JDE is jointly supported by the NSW Science Leveraging Fund and the Australian Research Council (DP120100728). MD is partly supported by the CSIRO Marine and Coastal Carbon Biogeochemistry Cluster. MD also acknowledges the support of the Australian Research Council Discovery Project Scheme (DP140101340 and DP1092892). Data was sourced from the Integrated Marine

Observing System (IMOS), an initiative of the Australian Government being conducted as part of the National Collaborative Research Infrastructure Strat- 
egy and the Super Science Initiative. The authors wish to thank the captain and crew of $R / V$ Southern Surveyor voyage SS09/2010 and the participating scientists, as well as Nagur Cherukuru for providing profiling photometer data and Lesley Clementson for HPLC analyses. We also acknowledge the MODIS mission scientists and associated NASA personnel for the production of the data used in this research effort. This manuscript is number XXXX from the Sydney Institute of Marine Science.

\section{References}

Armbrecht, L. H., Roughan, M., Rossi, V., Schaeffer, A., Davies, P. L., Waite, A. M., Armand, L. K., 2014. Phytoplankton composition under contrasting oceanographic conditions: Upwelling and downwelling (Eastern Australia). Continental Shelf Research 75 (C), 54-67.

Arthington, A. H., Pusey, B. J., 2003. Flow restoration and protection in Australian rivers. River Research and Applications 19 (5-6), 377-395.

Baird, M. E., Ridgway, K. R., 2012. The southward transport of sub-mesoscale lenses of Bass Strait Water in the centre of anti-cyclonic mesoscale eddies. Geophysical Research Letters 39, L02603.

Baird, M. E., Suthers, I. M., Griffin, D. A., Hollings, B., Pattiaratchi, C., Everett, J. D., Roughan, M., Doblin, M. A., 2011. The effect of surface flooding on the physical-biogeochemical dynamics of a warm-core eddy off southeast Australia. Deep Sea Research Part II: Topical Studies in Oceanography 58 (5), $592-605$.

Baird, M. E., Timko, P. G., Wu, L., 2007. The effect of packaging of chlorophyll within phytoplankton and light scattering in a coupled physical-biological ocean model. Marine and Freshwater Research 58 (10), 966-981.

Barnes, M. K., Tilstone, G. H., Smyth, T. J., Suggett, D. J., Astoreca, R., Lancelot, C., Kromkamp, J. C., 2014. Absorption-based algorithm of primary 
production for total and size-fractionated phytoplankton in coastal waters. Marine Ecology Progress Series 504, 73-89.

Behrenfeld, M. J., Boss, E., 2006. Beam attenuation and chlorophyll concentration as alternative optical indices of phytoplankton biomass. Journal of Marine Research 64, 431-451.

Behrenfeld, M. J., Boss, E., Siegel, D. A., Shea, D. M., 2005. Carbon-based ocean productivity and phytoplankton physiology from space. Global Biogeochemical Cycles 19 (1), GB1006.

Behrenfeld, M. J., Falkowski, P. G., 1997a. A consumer's guide to phytoplankton primary productivity models. Limnology and Oceanography, 1479-1491.

Behrenfeld, M. J., Falkowski, P. G., 1997b. Photosynthetic rates derived from satellite-based chlorophyll concentration. Limnology and Oceanography 42, $1-20$.

Brander, K. M., 2007. Global fish production and climate change. Proceedings of the National Academy of Sciences 104 (50), 19709-19714.

Brock, T. D., 1981. Calculating Solar-Radiation for Ecological-Studies. Ecological Modelling 14, 1-19.

Buitenhuis, E. T., Hashioka, T., Le Quéré, C., 2013. Combined constraints on global ocean primary production using observations and models. Global Biogeochemical Cycles 27, 1-12.

Carr, M.-E., Friedrichs, M. A. M., Schmeltz, M., Noguchi Aita, M., Antoine, D., Arrigo, K. R., Asanuma, I., Aumont, O., Barber, R., Behrenfeld, M., Bidigare, R., Buitenhuis, E. T., Campbell, J., Ciotti, A., Dierssen, H., Dowell, M., Dunne, J. P., Esaias, W., Gentili, B., Gregg, W. W., Groom, S., Hoepffner, N., Ishizaka, J., Kameda, T., Le Quéré, C., Lohrenz, S., Marra, J., Mélin, F., Moore, K., Morel, A., Reddy, T. E., Ryan, J., Scardi, M., Smyth, T., Turpie, K., Waters, K., Yamanaka, Y., 2006. A comparison of global estimates of 
marine primary production from ocean color. Deep Sea Research Part II: Topical Studies in Oceanography 53 (5-7), 741-770.

Carr, M.-E., Kearns, E. J., 2003. Production regimes in four Eastern Boundary Current systems. Deep Sea Research Part II: Topical Studies in Oceanography 50, 3199-3221.

Chassot, E., Bonhommeau, S., Dulvy, N. K., Mélin, F., Watson, R., Gascuel, D., Le Pape, O., 2010. Global marine primary production constrains fisheries catches. Ecology Letters 13 (4), 495-505.

Chassot, E., Bonhommeau, S., Reygondeau, G., Nieto, K., Polovina, J. J., Huret, M., Dulvy, N. K., Demarcq, H., 2011. Satellite remote sensing for an ecosystem approach to fisheries management. ICES Journal of Marine Science 68 (4), 651-666.

Chavez, F. P., Messié, M., Pennington, J. T., 2011. Marine Primary Production in Relation to Climate Variability and Change. Annual Review of Marine Science 3 (1), 227-260.

Cherukuru, N., Brando, V. E., Schroeder, T., Clementson, L. A., Dekker, A. G., 2014. Influence of river discharge and ocean currents on coastal optical properties. Continental Shelf Research 84 (C), 188-203.

Condie, S. A., Dunn, J. R., 2006. Seasonal characteristics of the surface mixed layer in the Australasian region: implications for primary production regimes and biogeography. Marine and Freshwater Research 57, 569-590.

Darecki, M., Stramski, D., 2004. An evaluation of MODIS and SeaWiFS biooptical algorithms in the Baltic Sea. Remote Sensing of Environment 89 (3), 326-350.

Davis, J. R., Koop, K., 2006. Eutrophication in Australian Rivers, Reservoirs and Estuaries - A Southern Hemisphere Perspective on the Science and its Implications. Hydrobiologia 559 (1), 23-76. 
Eppley, R. W., 1972. Temperature and phytoplankton growth in the sea. Fisheries Bulletin 70 (4), 1063-1085.

Eppley, R. W., Peterson, B. J., 1979. Particulate organic matter flux and planktonic new production in the deep ocean. Nature 282, 677-680.

Eppley, R. W., Stewart, E., Abbott, M. R., Heyman, U., 1985. Estimating ocean primary production from satellite chlorophyll. Introduction to regional differences and statistics for the Southern California Bight. Journal of Plankton Research 7 (1), 57-70.

Everett, J. D., Baird, M. E., Roughan, M., Suthers, I. M., Doblin, M. A., 2014. Relative impact of seasonal and oceanographic drivers on surface chlorophyll a along a Western Boundary Current. Progress in Oceanography 120, 340-351.

Everett, J. D., Baird, M. E., Suthers, I. M., 2012. An avenue of eddies: Quantifying the biophysical properties of mesoscale eddies in the Tasman Sea. Geophysical Research Letters 39 (16), L16608.

Everett, J. D., Macdonald, H., Baird, M. E., Humphries, J., Roughan, M., Suthers, I. M., in press Cyclonic entrainment of preconditioned shelf waters into a frontal eddy. Journal of Geophysical Research: Oceans.

Falkowski, P. G., Kolber, Z., 1995. Variations in Chlorophyll Fluorescence Yields in Phytoplankton in the World Oceans. Australian Journal of Plant Physiology $22,341-355$.

Friedrichs, M. A. M., Carr, M.-E., Barber, R. T., Scardi, M., Antoine, D., Armstrong, R. A., Asanuma, I., Behrenfeld, M. J., Buitenhuis, E. T., Chai, F., Christian, J. R., Ciotti, A. M., Doney, S. C., Dowell, M., Dunne, J. P., Gentili, B., Gregg, W. W., Hoepffner, N., Ishizaka, J., Kameda, T., Lima, I., Marra, J., Mélin, F., Moore, J. K., Morel, A., O’Malley, R. T., O’Reilly, J., Saba, V. S., Schmeltz, M., Smyth, T. J., Tjiputra, J., Waters, K., Westberry, T. K., Winguth, A., 2009. Assessing the uncertainties of model estimates of 
primary productivity in the tropical Pacific Ocean. Journal of Marine Systems 76 (1-2), 113-133.

Furnas, M. J., 2007. Intra-seasonal and inter-annual variations in phytoplankton biomass, primary production and bacterial production at North West Cape, Western Australia: Links to the 1997-1998 El Niño event. Continental Shelf Research 27 (7), 958-980.

Furnas, M. J., Mitchell, A. W., 1987. Phytoplankton dynamics in the central Great Barrier Reef-II. Primary production. Continental Shelf Research 7 (9), 1049-1062.

Furnas, M. J., Mitchell, A. W., 1996. Pelagic primary production in the Coral and southern Solomon Seas. Marine and Freshwater Research 47 (5), 695-706.

Griffiths, F. B., Bates, T. S., Quinn, P. K., Clementson, L. A., Parslow, J. S., 1999. Oceanographic context of the First Aerosol Characterization Experiment (ACE 1): A physical, chemical, and biological overview 104 (D17), 21649-21671.

Hama, T., Miyazaki, T., Iwakuma, T., Takahashi, M., Ichimura, S., 1983. Measurement of photosynthetic production of a marine phytoplankton population using a stable ${ }^{13} \mathrm{C}$ isotope. Marine Biology 73 (1), 31-36.

Hanson, C. E., Pattiaratchi, C. B., Waite, A. M., 2005. Sporadic upwelling on a downwelling coast: Phytoplankton responses to spatially variable nutrient dynamics off the Gascoyne region of Western Australia. Continental Shelf Research 25 (12-13), 1561-1582.

Hassler, C. S., Sinoir, M., Clementson, L. A., Butler, E. C. V., 2012. Exploring the link between micronutrients and phytoplankton in the Southern Ocean during the 2007 austral summer. Frontiers in Microbiology 3, 1-26.

Hung, T.-C., 1975. Primary production in the Kuroshio Current surrounding Taiwan. Journal of the Oceanographical Society of Japan 31 (6), 255-258. 
Huot, Y., Babin, M., Bruyant, F., Grob, C., Twardowski, M. S., Claustre, H., 2007. Relationship between photosynthetic parameters and different proxies of phytoplankton biomass in the subtropical ocean. Biogeosciences 4 (5), 853868.

Jacox, M. G., Edwards, C. A., Kahru, M., Rudnick, D. L., Kudela, R. M., 2015. The potential for improving remote primary productivity estimates through subsurface chlorophyll and irradiance measurement. Deep Sea Research Part II: Topical Studies in Oceanography 112 (c), 107-116.

Jones, E. M., Doblin, M. A., Matear, R., King, E., 2015. Assessing and evaluating the ocean-colour footprint of a regional observing system. Journal of Marine Systems 143, 49-61.

Juranek, L. W., Quay, P. D., 2010. Basin-wide photosynthetic production rates in the subtropical and tropical Pacific Ocean determined from dissolved oxygen isotope ratio measurements. Global Biogeochemical Cycles 24 (2), GB2006.

Kahru, M., Kudela, R., Manzano-Sarabia, M., Mitchell, B. G., 2009. Trends in primary production in the California Current detected with satellite data 114 (C2), C02004.

Kameda, T., Ishizaka, J., 2005. Size-fractionated primary production estimated by a two-phytoplankton community model applicable to ocean color remote sensing. Journal of Oceanography 61 (4), 663-672.

Kirk, J. T. O., 2011. Light and Photosynthesis in Aquatic Systems, 3rd Edition. Cambridge University Press.

Lawrenz, E., Silsbe, G., Capuzzo, E., Ylöstalo, P., Forster, R. M., Simis, S. G. H., Prášil, O., Kromkamp, J. C., Hickman, A. E., Moore, C. M., Forget, M.-H., Geider, R. J., Suggett, D. J., 2013. Predicting the Electron Requirement for Carbon Fixation in Seas and Oceans. PLoS ONE 8 (3), e58137. 
Le, C., Hu, C., English, D., Cannizzaro, J., Chen, Z., Feng, L., Boler, R., Kovach, C., 2013. Towards a long-term chlorophyll-a data record in a turbid estuary using MODIS observations. Progress in Oceanography 109 (C), 90103.

Lewis, M. R., Smith, J. C., 1983. A small volume, short-incubation-time method for measure-ment of photosynthesis as a function of incident irradiance. Marine Ecology Progress Series 13, 99-102.

Longhurst, A., Sathyendranath, S., Platt, T., Caverhill, C., 1995. An estimate of global primary production in the ocean from satellite radiometer data. Journal of Plankton Research 17 (6), 1245-1271.

Lourey, M. J., Thompson, P. A., McLaughlin, M. J., Bonham, P., Feng, M., 2012. Primary production and phytoplankton community structure during a winter shelf-scale phytoplankton bloom off Western Australia. Marine Biology 160 (2), 355-369.

Mitchell-Innes, B. A., 1967. Primary production studies in the south-west Indian Ocean, 1961-1963. Tech. rep., Durban, Republic of South Africa.

Mouw, C. B., Yoder, J. A., 2005. Primary production calculations in the MidAtlantic Bight, including effects of phytoplankton community size structure. Limnology and Oceanography, 1232-1243.

Platt, T., Gallegos, C. L., Harrison, W. G., 1980. Photoinhibition of Photosynthesis in Natural Assemblages of Marine-Phytoplankton. Journal of Marine Research 38 (4), 687-701.

Probyn, T. A., Mitchell-Innes, B. A., Brown, P. C., Hutchings, L., Carter, R. A., 1994. A review of primary production and related processes on the Agulhas Bank. South African Journal of Science 90, 166-173.

Probyn, T. A., Mitchell-Innes, B. A., Searson, S., 1995. Primary productivity and nitrogen uptake in the subsurface chlorophyll maximum on the Eastern Agulhas Bank. Continental Shelf Research 15 (15), 1903-1920. 
Roughan, M., Middleton, J. H., 2002. A comparison of observed upwelling mechanisms off the east coast of Australia. Continental Shelf Research 22 (17), $2551-2572$.

Saba, V. S., Friedrichs, M. A. M., Antoine, D., Armstrong, R. A., Asanuma, I., Behrenfeld, M. J., Ciotti, A. M., Dowell, M., Hoepffner, N., Hyde, K. J. W., Ishizaka, J., Kameda, T., Marra, J., Mélin, F., Morel, A., O’Reilly, J., Scardi, M., Smith Jr., W. O., Smyth, T. J., Tang, S., Uitz, J., Waters, K., Westberry, T. K., 2011. An evaluation of ocean color model estimates of marine primary productivity in coastal and pelagic regions across the globe. Biogeosciences $8(2), 489-503$.

Saba, V. S., Friedrichs, M. A. M., Carr, M.-E., Antoine, D., Armstrong, R. A., Asanuma, I., Aumont, O., Bates, N. R., Behrenfeld, M. J., Bennington, V., Bopp, L., Bruggeman, J., Buitenhuis, E. T., Church, M. J., Ciotti, A. M., Doney, S. C., Dowell, M., Dunne, J. P., Dutkiewicz, S., Gregg, W. W., Hoepffner, N., Hyde, K. J. W., Ishizaka, J., Kameda, T., Karl, D. M., Lima, I., Lomas, M. W., Marra, J., McKinley, G. A., Mélin, F., Moore, J. K., Morel, A., Salihoglu, B., Scardi, M., Smyth, T. J., Tang, S., Tjiputra, J., Uitz, J., Vichi, M., Waters, K., Westberry, T. K., Yool, A., 2010. Challenges of modeling depth-integrated marine primary productivity over multiple decades: A case study at BATS and HOT. Global Biogeochemical Cycles 24, GB3020.

Siegel, D. A., Maritorena, S., Nelson, N. B., 2005. Colored dissolved organic matter and its influence on the satellite-based characterization of the ocean biosphere. Geophysical Research Letters, L20605.

Son, S., Wang, M., Shon, J.-K., 2011. Satellite observations of optical and biological properties in the Korean dump site of the Yellow Sea. Remote Sensing of Environment 115 (2), 562-572.

Steemann-Nielsen, E., 1952. The use of radio-active carbon (C14) for measuring organic production in the sea. Journal du Conseil 18 (2), 117-140. 
Suthers, I. M., Young, J. W., Baird, M. E., Roughan, M., Everett, J. D., Brassington, G. B., Byrne, M., Condie, S. A., Hartog, J. R., Hassler, C. S., Hobday, A. J., Holbrook, N. J., Malcolm, H. A., Thompson, P. A., Ridgway, K. R., 2011. The strengthening East Australian Current, its eddies and biological effects - an introduction and overview. Deep Sea Research Part II: Topical Studies in Oceanography 58 (5), 538-546.

Thompson, P. A., Bonham, P., Waite, A. M., Clementson, L. A., Cherukuru, N., Hassler, C., Doblin, M. A., 2011. Contrasting oceanographic conditions and phytoplankton communities on the east and west coasts of Australia. Deep Sea Research Part II: Topical Studies in Oceanography 58 (5), 645-663.

Van Heukelem, L., Thomas, C. S., 2001. Computer-assisted high-performance liquid chromatography method development with applications to the isolation and analysis of phytoplankton pigments. Journal of Chromatography A $910(1), 31-49$.

van Ruth, P. D., Ganf, G. G., Ward, T. M., 2010. Hot-spots of primary productivity: An Alternative interpretation to Conventional upwelling models. Estuarine, Coastal and Shelf Science 90 (3), 142-158.

Werdell, P. J., Bailey, S. W., 2005. An improved in-situ bio-optical data set for ocean color algorithm development and satellite data product validation. Remote Sensing of Environment 98 (1), 122-140.

Westwood, K. J., Griffiths, B. F., Webb, J. P., Wright, S. W., Nov. 2011. Primary production in the Sub-Antarctic and Polar Frontal Zones south of Tasmania, Australia; SAZ-Sense survey, 2007. Deep Sea Research Part II: Topical Studies in Oceanography 58 (21-22), 2162-2178.

Wu, L., Cai, W., Zhang, L., Timmermann, A., Joyce, T., McPhaden, M. J., Alexander, M., Qiu, B., Visbeck, M., Chang, P., Giese, B., 2012. Enhanced warming over the global subtropical western boundary currents. Nature Climate Change 2 (1), 1-6. 
Zainuddin, M., Kiyofuji, H., Saitoh, K., Saitoh, S.-I., 2006. Using multi-sensor satellite remote sensing and catch data to detect ocean hot spots for albacore (Thunnus alalunga) in the northwestern North Pacific. Deep Sea Research Part II: Topical Studies in Oceanography 53 (3-4), 419-431. 
$\frac{0}{\frac{0}{0}}$ 


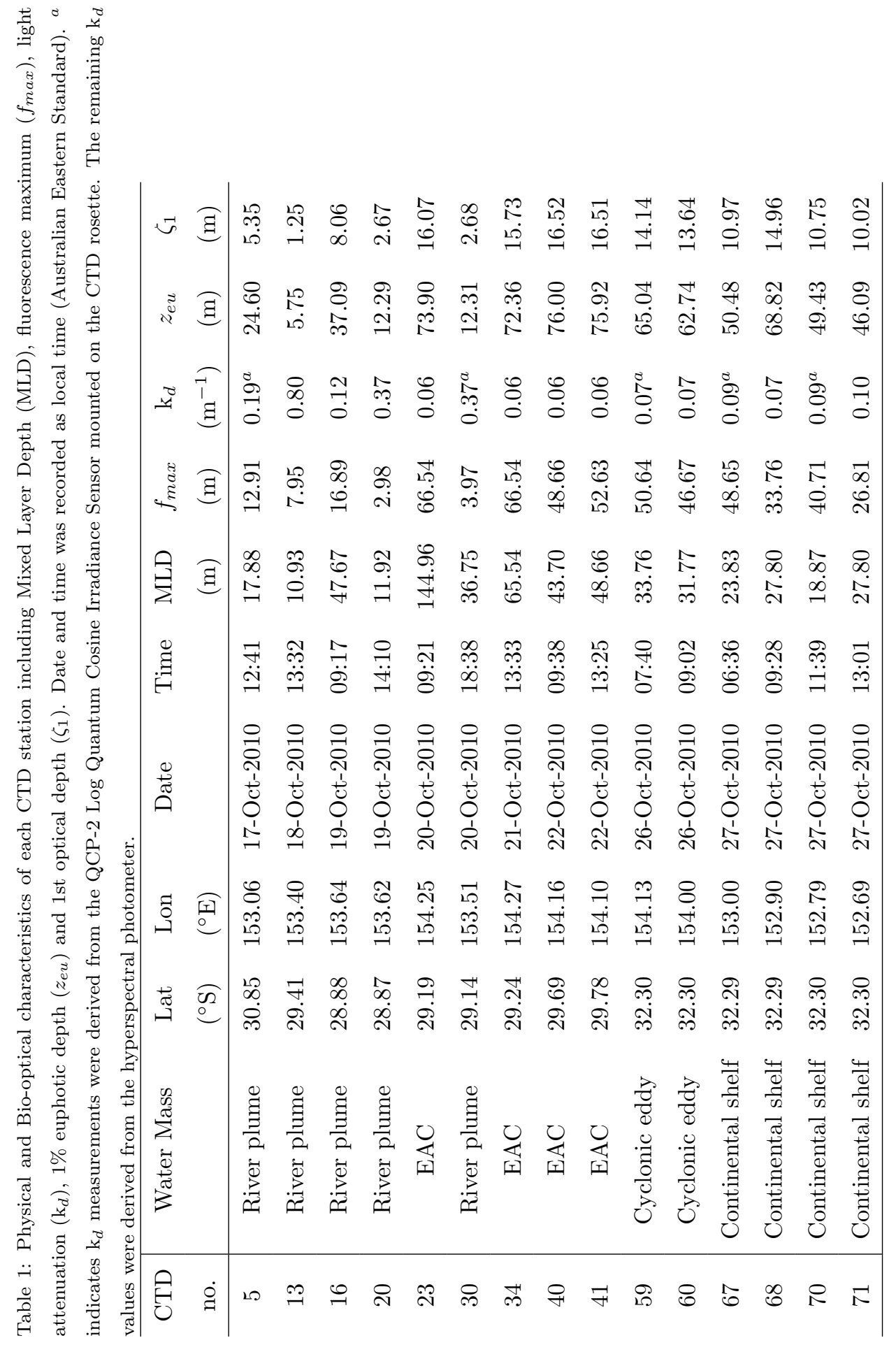




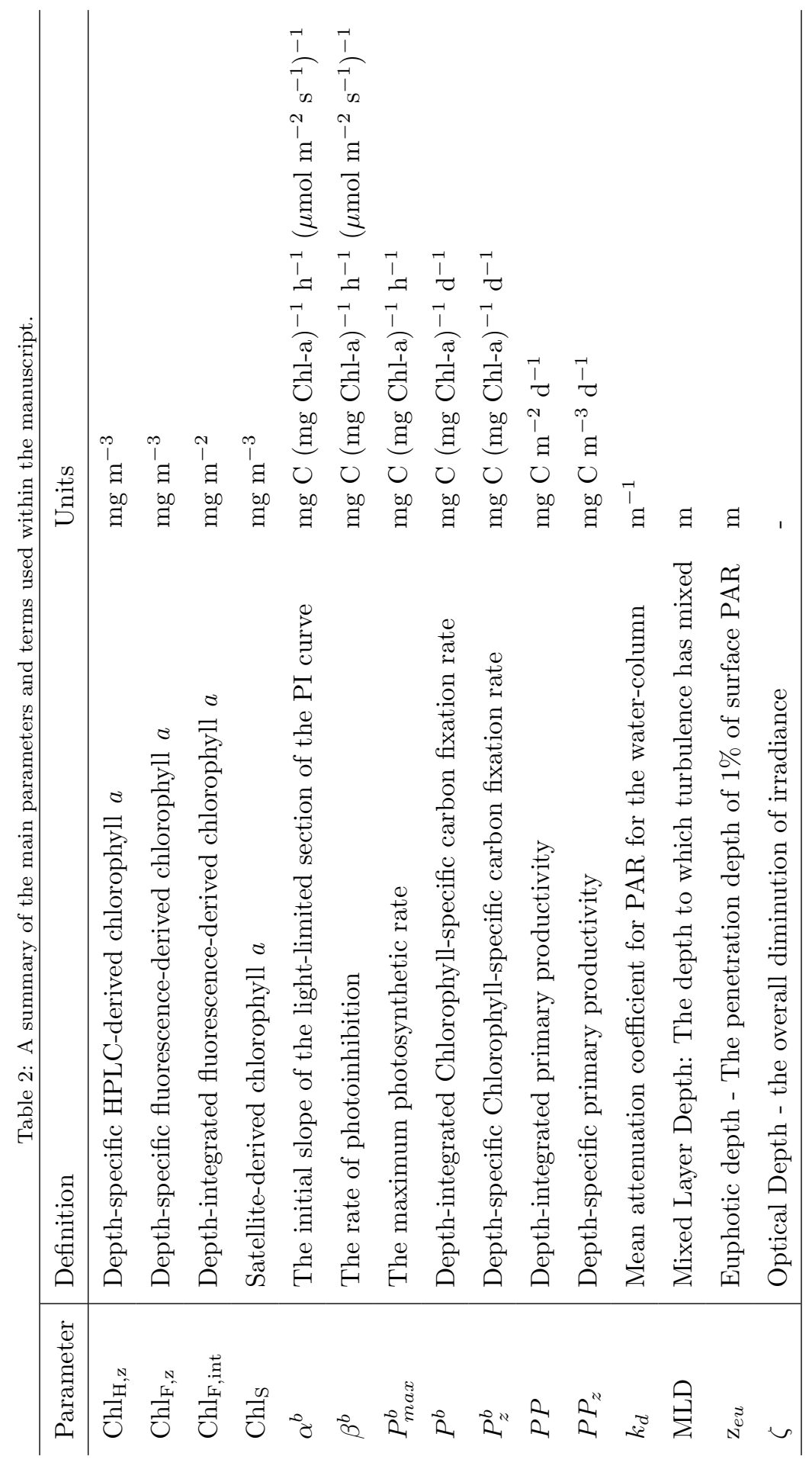


Table 3: Average (and range) values for $\alpha^{b}, \beta^{b}$ and $\mathrm{P}_{\max }^{b}$ for each water-mass used for calculations of PP estimates. The surface and $f_{\max }$ values are shown separately.

\begin{tabular}{|c|c|c|c|}
\hline Water-Mass & $\alpha^{b}$ & $\beta^{b}$ & $\mathrm{P}_{\max }^{b}$ \\
\hline \multicolumn{4}{|l|}{ Surface: } \\
\hline River plume & $0.11(0.07-0.14)$ & $0(0-0.01)$ & $12.69(9.38-16.12)$ \\
\hline $\mathrm{EAC}$ & $0.27(0.21-0.41)$ & $0.01(0-0.02)$ & $32.02(27.29-43.88)$ \\
\hline Cyclonic eddy & $0.08(0.08-0.08)$ & $0.01(0-0.01)$ & $9.48(8.75-10.21)$ \\
\hline Continental shelf & $0.09(0.07-0.12)$ & $0.01(0-0.02)$ & $11.88(9.07-14.11)$ \\
\hline \multicolumn{4}{|l|}{$f_{\max }:$} \\
\hline River plume & $0.12(0.07-0.18)$ & $0.01(0-0.02)$ & $9.15(3.13-12.83)$ \\
\hline $\mathrm{EAC}$ & $0.46(0.26-0.64)$ & $0.05(0.02-0.07)$ & $19.72(11.03-31.06)$ \\
\hline Cyclonic eddy & $0.06(0.05-0.08)$ & $0(0-0)$ & $3.54(2.86-4.21)$ \\
\hline Continental shelf & $0.07(0.03-0.12)$ & $0.02(0-0.04)$ & $5.15(2.27-7.82)$ \\
\hline
\end{tabular}




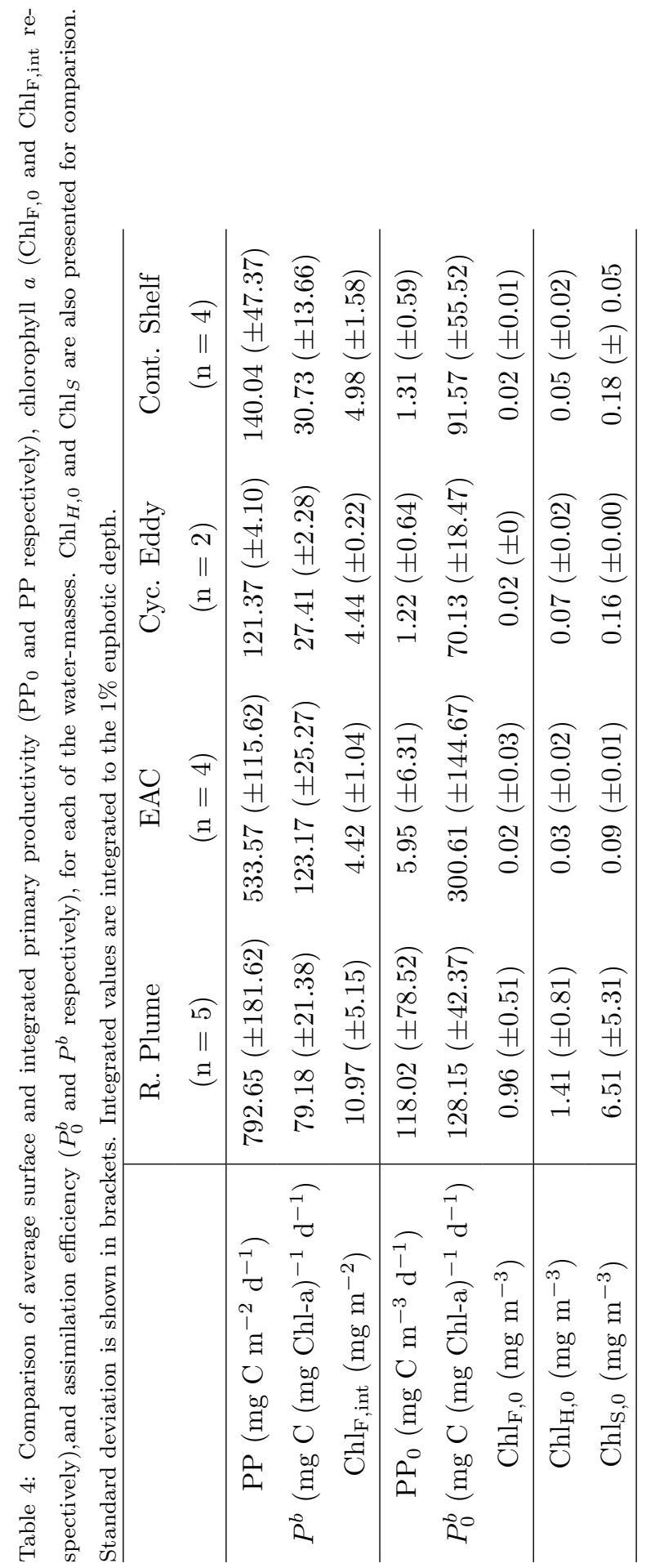


Table 5: Overall model skill (RMSD) and bias for the four models - ESQRT, VGPM, VGPMEppley and VGPM-Kameda. Model skill and bias are presented for both satellite- and CTDinputs $\left(\mathrm{Chl}_{H}\right.$ and $\left.\mathrm{Chl}_{F}\right)$. The lower the RMSD and lower the $\mid$ bias $\mid$, the better the model. The best model results are highlighted in bold.

\begin{tabular}{c|cccc}
\hline Model & Input Data & $\mathrm{n}$ & RMSD & Bias \\
\hline ESQRT & MODIS-Aqua & 15 & $\mathbf{0 . 2 9}$ & $\mathbf{0 . 1 2}$ \\
VGPM & MODIS-Aqua & 15 & 0.48 & 0.33 \\
VGPM-Eppley & MODIS-Aqua & 15 & 0.41 & 0.22 \\
VGPM-Kameda & MODIS-Aqua & 15 & 0.40 & 0.29 \\
\hline ESQRT & CTD w/ Chl & 15 & 0.30 & -0.14 \\
VGPM & CTD w/ Chl & 15 & 0.38 & $\mathbf{- 0 . 0 3}$ \\
VGPM-Eppley & CTD w/ Chl & 15 & 0.39 & -0.15 \\
VGPM-Kameda & CTD w/ Chl & 15 & $\mathbf{0 . 2 5}$ & 0.11 \\
\hline ESQRT & CTD w/ Chl & 15 & 0.45 & -0.34 \\
VGPM & CTD w/ Chl & 15 & 0.57 & -0.34 \\
VGPM-Eppley & CTD w/ Chl & 15 & 0.64 & -0.45 \\
VGPM-Kameda & CTD w/ Chl & 15 & $\mathbf{0 . 2 4}$ & $\mathbf{0 . 0 5}$ \\
\hline
\end{tabular}


Table 6: A summary of primary production measurements in Australian waters. Both mean ( \pm standard deviation) and range is presented where available. Nth $=$ Northern; NW $=$ Northwestern; EAC = East Australian Current; GBR = Great Barrier Reef

\begin{tabular}{llll}
\hline Region & Season & Year & $\begin{array}{l}\text { Primary Production } \\
\left(\mathrm{mg} \mathrm{C} \mathrm{m}^{-2} \mathrm{~d}^{-1}\right)\end{array}$ \\
\hline Winter/Spring & & & \\
Coral Sea & Jun-Jul & 1988 & $459-654(431 \pm 211)^{1}$ \\
Coral Sea & Oct & 1985 & $117-330(557 \pm 244)^{1}$ \\
Nth. GBR \& EAC & Jun-Jul & 1988 & $780-944(841 \pm 90)^{1}$ \\
Nth. GBR \& EAC & Oct & 1985 & $189-356(284 \pm 73)^{1}$ \\
Central GBR & May-Oct, & $1983-1985$ & $217-598(394 \pm 179)^{2}$ \\
Tropical EAC & May-Oct & $1983-1985$ & $251-1456(796 \pm 611)^{2}$ \\
Temperate EAC & Oct & 2010 & $417-661(534 \pm 116)^{3}$ \\
Leeuwin Current & Nov & 2000 & $110-530(200 \pm 127)^{4}$ \\
Leeuwin Current & May-Jun & 2007 & $152 \pm 33(\text { upstream of eddy })^{5}$ \\
Leeuwin Current & May-Jun & 2007 & $370 \pm 112(\text { downstream of eddy })^{5}$
\end{tabular}

\section{Summer/Autumn}

Central GBR

Tropical EAC

NW Australian shelf

NW Australian shelf

Great Australian Bight

Great Australian Bight

Southern Ocean

Southern Ocean

\begin{tabular}{|c|c|c|}
\hline Nov-April, & $1983-1985$ & $206-974(548 \pm 233)^{2}$ \\
\hline Nov-April & $1983-1985$ & $142-755(313 \pm 226)^{2}$ \\
\hline Dec-Feb & $1997-1998$ & $2,700 \pm 900(\text { Station B })^{6}$ \\
\hline Dec-Feb & 1997-1998 & $3,100 \pm 2,200(\text { Station } \mathrm{E})^{6}$ \\
\hline Feb-Mar & 2005-2006 & $<800$ (eastern, central, western $)^{7}$ \\
\hline Feb-Mar & $2005-2006$ & 800-1600 (mid shelf, coastal) ${ }^{7}$ \\
\hline Nov-Dec & 1995 & $409{\text { (polar front })^{8}}^{2}$ \\
\hline Nov-Dec & 1995 & 3180 (subtropical) $^{8}$ \\
\hline
\end{tabular}

${ }^{1}$ Furnas and Mitchell (1996), ${ }^{2}$ Furnas and Mitchell (1987), ${ }^{3}$ This study, ${ }^{4}$ Hanson et al. (2005),

${ }^{5}$ Lourey et al. (2012), ${ }^{6}$ Furnas (2007), ${ }^{7}$ van Ruth et al. (2010), ${ }^{8}$ Griffiths et al. (1999) 


\section{Figures}
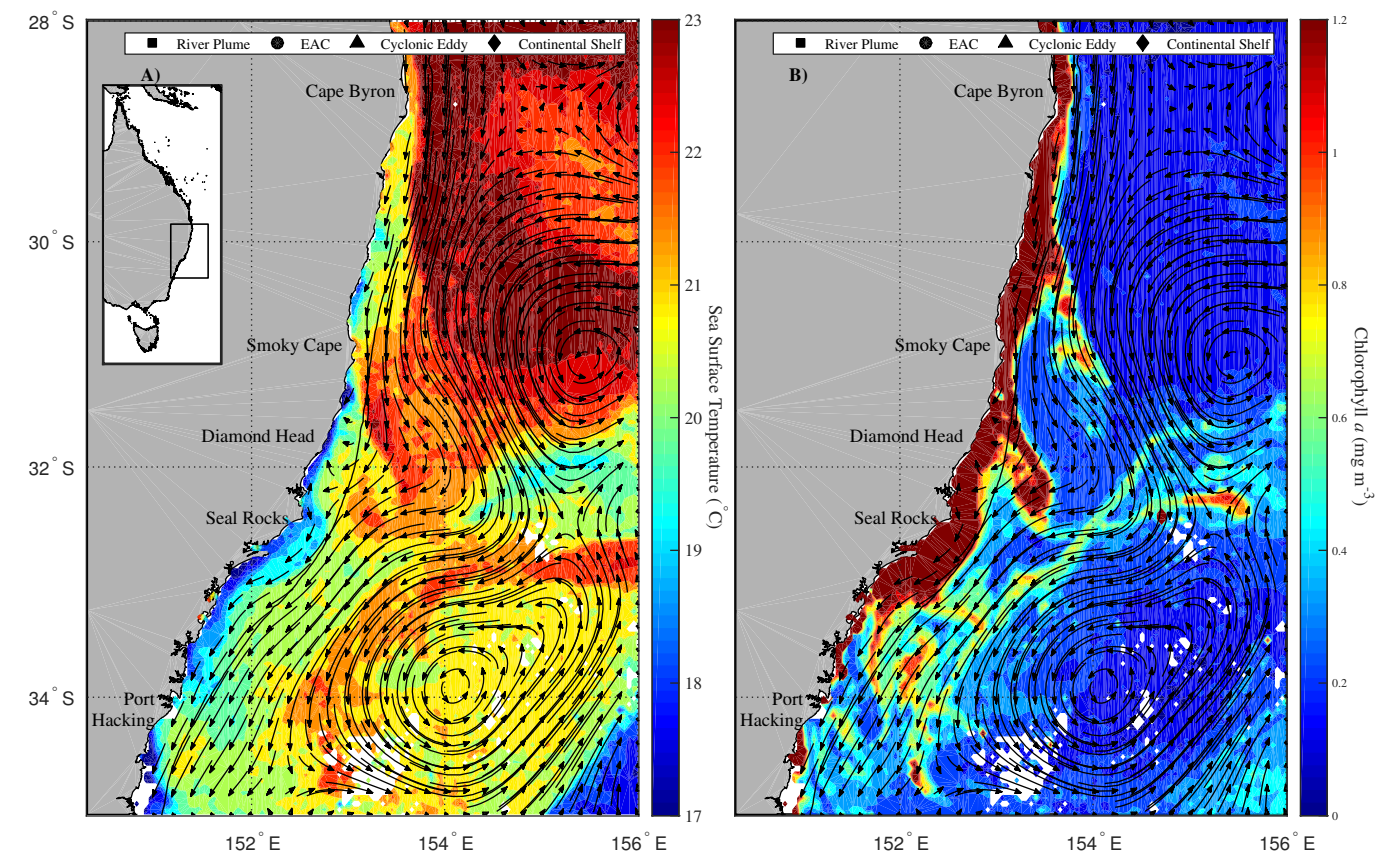

Figure 1: Location map of southeast Australia showing A) Sea Surface Temperature and B) Chl-a biomass from MODIS-Aqua Ocean Colour (L3 OC3). Arrows represent Lagrangian paths for the $24 \mathrm{~h}$ leading up to the midday satellite pass. The $200 \mathrm{~m}$ isobath is shown as a black line. The black and white circles denote the sampling locations. See Table 1 for a complete description of station locations and properties. 

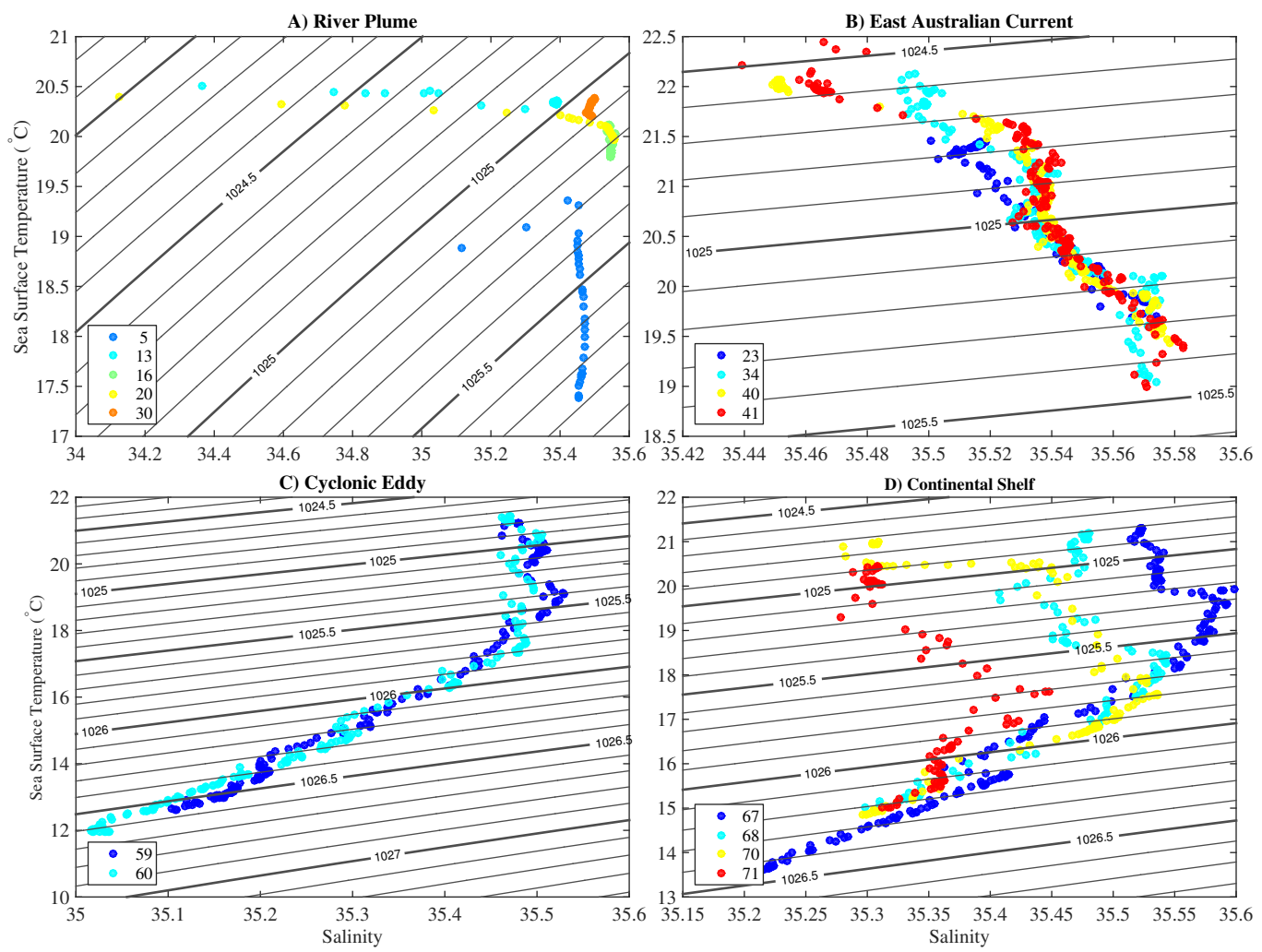

Figure 2: Temperature-Salinity plots for the 4 water-masses of A) River plumes (27$47 \mathrm{~m})$, B) East Australian Current (0-200 m), C) Cyclonic eddy (0-200 m) and D) Continental shelf $(0-200 \mathrm{~m})$. The grey contours show the corresponding isopycnals $(\mathrm{kg}$ $\left.\mathrm{m}^{-3}\right)$. 

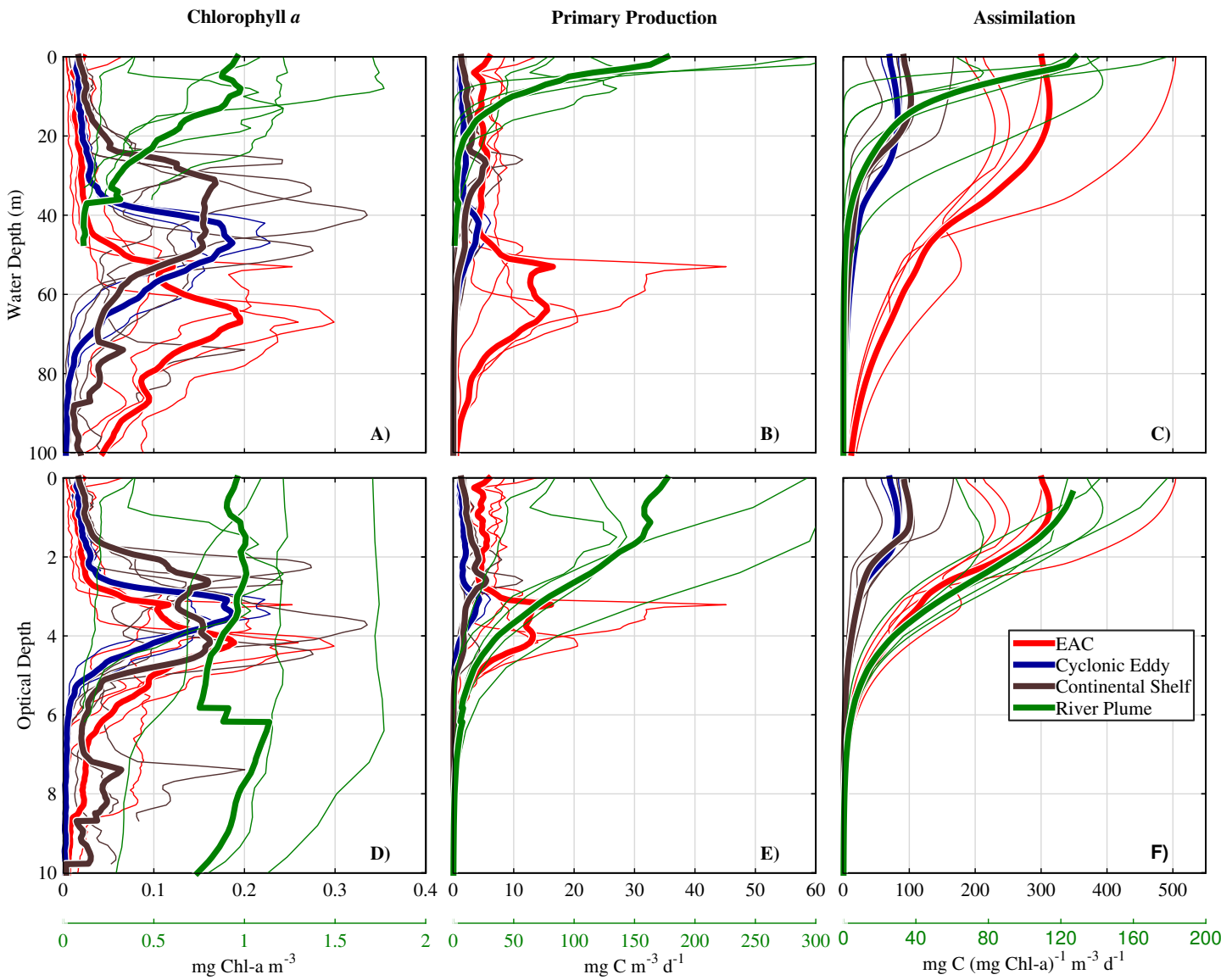

Figure 3: Vertical profiles of $\mathrm{Chl}_{\mathrm{F}}\left(\mathrm{A}\right.$ and $\mathrm{D} ; \mathrm{mg} \mathrm{m}^{-3}$ ), Primary Production (B and $\mathrm{E} ; \mathrm{mg} \mathrm{C} \mathrm{m} \mathrm{m}^{-3} \mathrm{~d}^{-1}$ ) and Assimilation (C and $\left.\mathrm{F} ; \mathrm{mg} \mathrm{C}(\mathrm{mg} \mathrm{Chl}-\mathrm{a})^{-1} \mathrm{~d}^{-1}\right)$ in relation to water depth (A-C) and Optical Depth (D-F). Water-masses are shown in different colours. The primary (black) x-axis corresponds to the EAC, continental shelf and cyclonic eddy stations. The secondary (green) $\mathrm{x}$-axis corresponds to the river plume stations (also in green). Individual profiles for each station are shown as thin lines and a mean profile for each water-mass is shown as a thicker line. 

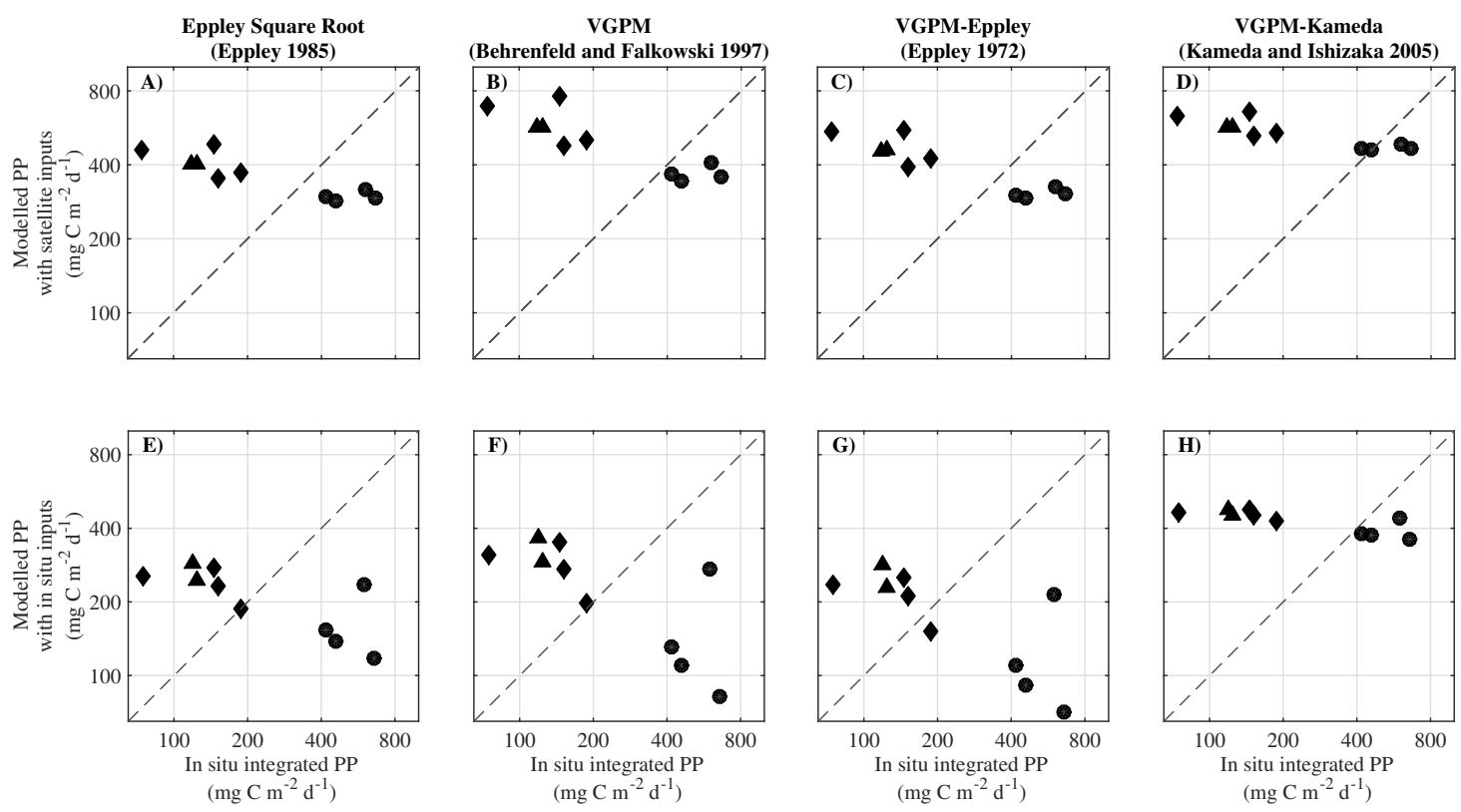

- EAC $\Delta$ Cyclonic Eddy $\bullet$ Continental Shelf

Figure 4: Correlations of vertically-integrated shipboard ${ }^{14} \mathrm{C} \mathrm{PP}$ measurements are shown against the output of four different productivity models (ESQRT, VGPM, VGPM-Eppley and VGPM-Kameda). Input variables for each model are both satellitederived (MODIS; top row) and in-situ (from CTD casts; bottom row). The dashed line indicates the 1:1 relationship. 

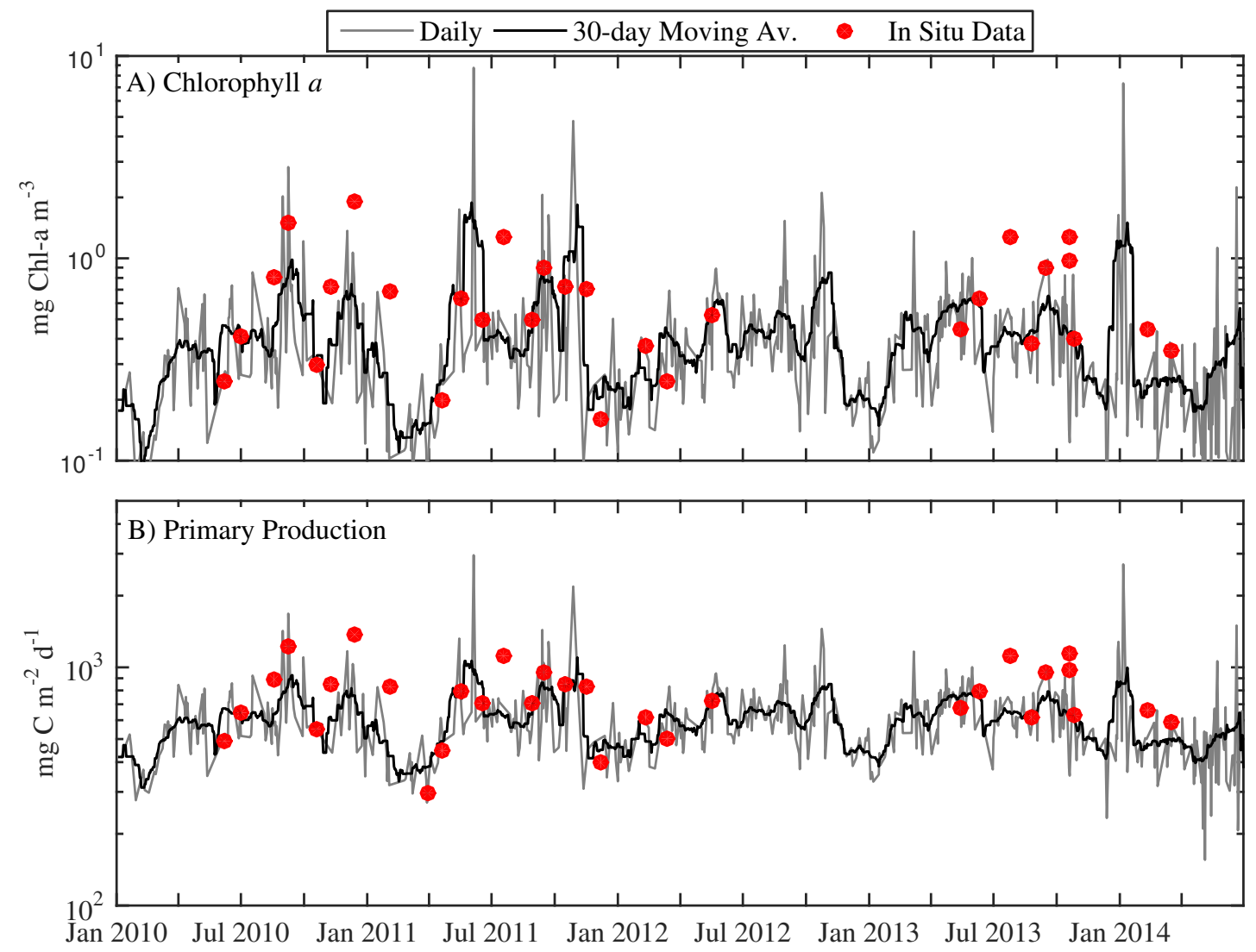

Figure 5: Daily Satellite-derived A) Chlorophyll $a$ and B) PP estimated using the ESQRT model are shown in grey for Port Hacking for the period 2010-2014. The black line represents the 30 day running average. The circle in A) represents the HPLC-derived Chlorophyll $a$ collected in-situ. The circle in B) represents the ESQRT modelled PP calculated using this HPLC-derived Chlorophyll $a$. 